\title{
Extracellular vesicles: novel communicators in lung diseases
}

Aradhana Mohan', Stuti Agarwal', Matthias Clauss², Nicholas S. Britt ${ }^{3,4}$ and Navneet K. Dhillon ${ }^{1,5^{*}}$

\begin{abstract}
The lung is the organ with the highest vascular density in the human body. It is therefore perceivable that the endothelium of the lung contributes significantly to the circulation of extracellular vesicles (EVs), which include exosomes, microvesicles, and apoptotic bodies. In addition to the endothelium, EVs may arise from alveolar macrophages, fibroblasts and epithelial cells. Because EVs harbor cargo molecules, such as miRNA, mRNA, and proteins, these intercellular communicators provide important insight into the health and disease condition of donor cells and may serve as useful biomarkers of lung disease processes. This comprehensive review focuses on what is currently known about the role of EVs as markers and mediators of lung pathologies including COPD, pulmonary hypertension, asthma, lung cancer and ALI/ARDS. We also explore the role EVs can potentially serve as therapeutics for these lung diseases when released from healthy progenitor cells, such as mesenchymal stem cells.
\end{abstract}

\section{Extracellular vesicles}

Cell-to-cell communication is essential for nearly all physiologic and metabolic processes. This intercellular conveyance is achieved through receptor ligands, signaling molecules, hormones, and extracellular vesicles (EVs). Historically, secretion of the cell in the form of EVs was considered as unimportant waste material, cellular "garbage bags," or dust particles [1-5]. However, in recent years, this so-called "waste" is now known to be of profound importance in various biological systems, creating a boon in their exploration across the scientific community.

Lipid bilayer membrane-enclosed vesicles are secreted by both prokaryotic and eukaryotic cells [4-9]. Although, the term "extracellular vesicle" is sometimes used in reference to exosomes, it is actually a very broad term that encompasses all different types of vesicles

\footnotetext{
* Correspondence: ndhillon@kumc.edu

'Division of Pulmonary and Critical Care Medicine, Department of Internal Medicine, University of Kansas Medical Center, Mail Stop 3007, 3901 Rainbow Blvd, Kansas City, KS 66160, USA

${ }^{5}$ Department of Molecular \& Integrative Physiology, University of Kansas Medical Center, Kansas City, Kansas, USA

Full list of author information is available at the end of the article
}

secreted outside the cells [10]. Regardless, the function of all these vesicles appears to be all the same: communication between the cells within an organism or between species [11, 12]. In addition, it is not necessary that all vesicles secreted from cells are functional or have any role in some kind of biological process. Sometimes, they just act as "dustcart" to remove the waste from cells [13]. Of note, there have been discrepancies in the classification of these vesicles in the literature. Some studies divide EVs into two major categories: I) exosomes, defined as vesicles released by exocytosis of the multivesicular bodies; and II) ectosomes, defined as the vesicles which are assembled and released by the plasma membrane [14]. However, most recent studies categorize EVs as either exosome, microvesicles, microparticles, or apoptotic bodies based on vesicle size and how they are formed [15-21] (Fig. 1).

\section{Exosomes}

Exosomes are small EVs with sizes ranging between 30 and $150 \mathrm{~nm}$ in diameter that originate from the internal vesicles of multivesicular bodies (MVB) of nearly all cell types. Exosomes originating from different cell types have different composition; however, there are certain 


\section{Exosomes}

$30-150 \mathrm{~nm}$
Microvesicles

$50-1000 \mathrm{~nm}$

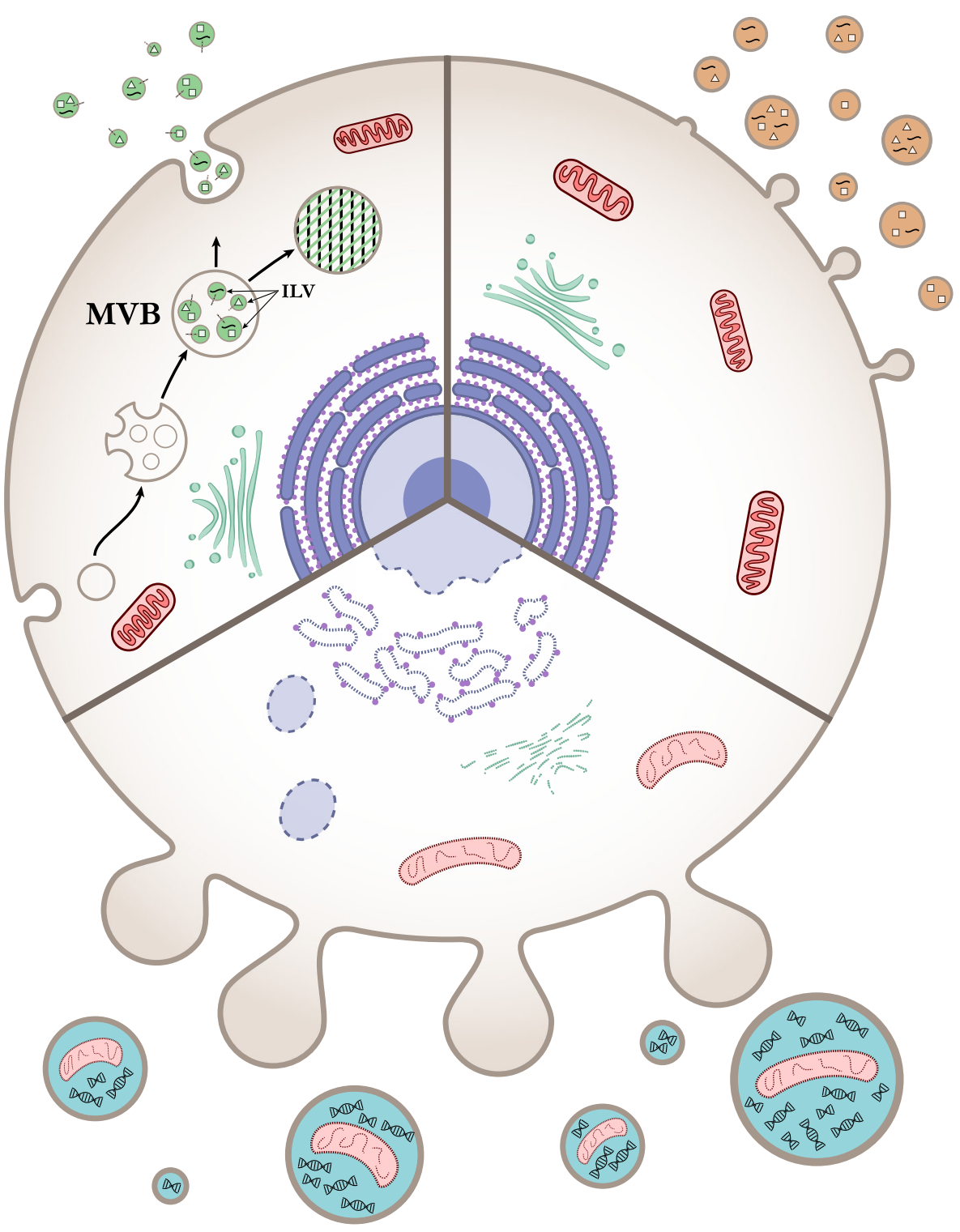

\section{Apoptotic Bodies}

$50-5000 \mathrm{~nm}$

$$
\begin{aligned}
& \stackrel{=- \text { Receptors }}{\triangle \text { Lipids }} \\
& \square \text { Proteins }
\end{aligned}
$$

\section{Mitochondria}

Golgi Apparatus

Endoplasmic Reticulum \& Ribosomes 
(See figure on previous page.)

Fig. 1 Biogenesis of various forms of extracellular vesicles from a eukaryotic cell. Exosomes are generated through multivesicular bodies (MVB) and intraluminal vesicles (ILV) formation whereas microvesicles/microparticles and apoptotic bodies are vesicles generated through blebbing of plasma membrane

characteristics, which are common to all exosomes regardless of their source. They usually sediment between $\sim 70,000-200,000 \times \mathrm{g}$ and their molecular cargo consists of proteins, lipids and nucleic acid molecules [22-24]. There are two basic mechanisms reported for the formation of MVBs and intraluminal vesicles (ILVs) leading to exosome generation: I) ESCRT-dependent [24] [23]; and ii) ESCRT-independent $[25,26]$. Details of these mechanisms have been explained previously in multiple publications [26-36].

A typical exosome is surrounded by a phospholipid membrane that contains lipids characteristic of their cellular origin [37, 38] with high levels of cholesterol, sphingomyelin, and ceramide and detergent-resistant membrane domains (lipid rafts) [39, 40]. Also present are proteins associated with lipid rafts, such as glycosylphosphatidylinositol-anchored proteins and flotillin $[39,41]$. Some lipids are present in greater amounts in exosomes compared to their parent cells, thus improving the rigidity of the exosomal membrane [42, 43]. Components of the ESCRT complex, such as Alix and tumor susceptibility gene 101 (TSG101), involved in MVB biogenesis [44] [45] [46], are distinguishing proteins present on exosomes $[47,48]$. Another distinguishing feature of exosomes is the presence of tetraspanins, including CD9, CD63, CD81 and CD82 [49]. Other proteins present in exosomes includes cytosolic proteins, such as Rabs, which are involved in promoting exosome docking and membrane fusion events [50, 51], as well as annexins, which are proteins believed to regulate membrane cytoskeleton dynamics and membrane fusion events [50]. Myriad studies have shown the presence of nucleic acid cargo [49, 52-54] within exosomes that are functionally active when released in the recipient cells. This nucleic acid cargo may include a variety of noncoding RNAs including microRNA and long non-coding RNA (lncRNA), tRNA fragments, small-interfering RNAs, structural RNAs, small RNA transcripts and RNA-protein complexes. Other than different RNA species, exosomes also contain DNA which could represent the entire genome as well as the genomic mutations, making them excellent biomarkers [55-58]. In addition to chromosomal DNA, mitochondrial DNA has also been reported [59, 60].

\section{Microvesicles}

Microvesicles (MVs), or microparticles (MPs) (50-1000 $\mathrm{nm})$, are secreted by direct outward budding of the plasma membrane of living cells with release of membrane microvilli $[61,62]$. These vesicles are generally larger in size up to $\sim 1000 \mathrm{~nm}[18]$, but smaller vesicles $(\sim 50 \mathrm{~nm})$ also bud from the plasma membrane [63]. Microvesicles have also been reported in various shapes. Typical markers used for detecting MVs are integrins, selectins, and CD40 [62]. However, various other markers may be used dependent on the cell type from which they are secreted. Studies also suggest that the vesicles which sediment at $\sim 10,000-20,000 \mathrm{x}$ g represent microvesicles $[16,64,65]$. Since microvesicles are shed by the budding of the plasma membrane, their composition is same as that of plasma membrane, except that the lipid composition is uniformly distributed across the bilayer membrane of the microvesicles, in contrast to the asymmetrical distribution present on the two leaflets of the plasma membrane [66-68]. Although the shedding of MVs from cells takes place at resting state, some cells release MVs based upon the stimulant they receive. Purinergic receptors, P2Y receptors, phorbol esters, and calcium have been reported to be involved in the robust release of MVs [69-73].

\section{Apoptotic bodies}

Apoptotic bodies (also referred to as "apoptotic blebs" or "apoptotic vesicles") represent type of EVs released by the outward budding, blebbing, or fragmentation of the plasma membrane during the apoptosis of cells. These vesicles are generally larger in size, ranging from $50 \mathrm{~nm}$ to $3 \mu \mathrm{m}$ [62], with some studies suggesting sizes ranging from 1 to $5 \mu \mathrm{m}[24,65,74-76]$. The content of apoptotic bodies released from plasma membranes differs depending on cellular origin, but has been shown to contain DNA fragments and histones [65]. Apoptotic bodies originating from the endoplasmic reticulum are devoid of DNA and histones, but contain immature glycoepitopes $[65,77,78]$. When these vesicles are taken up by antigen-presenting or neighboring cells, it may lead to anti-inflammatory or tolerogenic response $[1,79,80]$.

With the exponential growth of EV research in recent years, this review attempts to comprehensively update and highlight the importance of EVs with regard to various pulmonary complications and disease states.

\section{Role of EVs in the pathogenesis of lung diseases Chronic obstructive pulmonary disease (COPD)}

Chronic obstructive pulmonary disease is characterized by severe airway inflammation and subsequent damage of the lung parenchyma. This hyper inflammatory response leads to destruction of the alveolar wall and 
Table 1 Potential extracellular vesicle markers in various lung complications

\begin{tabular}{|c|c|c|c|}
\hline Disease subtype & EV Source & Biomarkers & Ref. \\
\hline \multicolumn{4}{|l|}{ COPD } \\
\hline & Plasma & $\uparrow$ E-selectin-, VE-cadherin, PECAM positive MPs & [84-89] \\
\hline & Plasma & Ceramide levels in EMPs & [90] \\
\hline & Plasma & 个Platelet derived LMPs and EMPs & [85] \\
\hline \multicolumn{4}{|l|}{ Pulmonary Hypertension } \\
\hline \multirow{7}{*}{$\begin{array}{l}\text { Group I PAH (Idiopathic /Heritable/ } \\
\text { connective tissue associated PAH) }\end{array}$} & Plasma & $\uparrow C D 39$ expression and ATPase/ADPase activity & [91] \\
\hline & Plasma & $\begin{array}{l}\text { Translationally controlled tumor protein (TCTP) } \\
\text { in endothelial derived EVs }\end{array}$ & [92] \\
\hline & Plasma & $\uparrow$ Endothelium derived exosomes & [93] \\
\hline & Plasma & $\begin{array}{l}\uparrow E M P s\left(C D 31^{+} \& \mathrm{CD}_{4} 1^{-}\right) \\
\text {Small Platelet derived MPs }\left(\mathrm{CD} 31^{+} / \mathrm{CD} 41^{+}\right)\end{array}$ & [94] \\
\hline & Plasma & $E M P s$ and LMPs & [95] \\
\hline & Plasma & $\uparrow C D 62 e+$ EMPs associated with adverse outcome & [96] \\
\hline & Urine & EMPs & [97] \\
\hline Group III PH & Plasma & $\uparrow$ Tissue factor and endoglin in EMPs & [98] \\
\hline \multirow[t]{2}{*}{ Group IV PH } & Plasma & $\uparrow$ Tissue factor and endoglin in EMPs & [98] \\
\hline & Plasma & $\uparrow P M P s$, LMPs and EMPs & [99] \\
\hline \multicolumn{4}{|l|}{ Asthma } \\
\hline & Blood & $\uparrow$ Eosinophil derived exoxomes & {$[100,101]$} \\
\hline & BALF & $\begin{array}{l}\uparrow \mathrm{CD} 63 \text { and } \mathrm{CD} 81^{+} \text {exosomes carrying leukotrienes } \\
\text { biosynthesis enzymes }\end{array}$ & [102] \\
\hline & BALF & $\uparrow$ Mitochondria/mitochondrial DNA in exosomes & [103] \\
\hline & BALF & $\begin{array}{l}\downarrow \text { Phosphatidylglycerol, ceramide-phosphates, and } \\
\text { ceramides }\end{array}$ & [104] \\
\hline & & $\uparrow$ Sphingomyelin in exosomes & \\
\hline \multicolumn{4}{|l|}{ Lung cancer } \\
\hline Late stage human lung cancer & Serum & $\uparrow$ Vimentin in exosomes & [105] \\
\hline Non-small Cell Lung Cancer & & 个IncRNA MALAT-1 in exosomes & [106] \\
\hline \multicolumn{4}{|l|}{ ALI/ARDS/ Pulmonary Sepsis } \\
\hline ARDS & BALF /plasma & $L M P S$ associated with better survival & [107] \\
\hline ARDS & Plasma & $\uparrow$ Gasdermin D in MPs & [108] \\
\hline ALI & Serum & $\begin{array}{l}\text { Apoptosis-associated speck-like protein containing } \\
\text { a caspase-recruiting domain (ASC) in EVs }\end{array}$ & [109] \\
\hline ARDS & Pulmonary edema fluid & Tissue Factor in MPs & [110] \\
\hline Sepsis / Community-acquired pneumonia -sepsis & Plasma & $\uparrow$ Alpha-2-macroglobuin in MVs/MPs correlates with survival & {$[111,112]$} \\
\hline
\end{tabular}

rarefaction of the alveolar sacs, causing difficulty in breathing and reduced pulmonary function, measured by total lung capacity and forced expiratory volume (FEV) [81]. The inflammatory response is most commonly incited by inhalation of toxic particles, chemical and radiological irritants, or cigarette smoke. Infections, which activate the toll like receptors (TLRs) present on resident lung cells, including alveolar macrophages, dendritic cells, alveolar epithelial cells and endothelial cells, may also contribute by stimulating the release of cytokines and chemokines [82]. Aside from the inflammatory processes of COPD, cells undergo senescence and aging (contributing to the senescence associated secretory phenotype [SASP]) [83] and release EVs that further contribute in the pathogenesis and progression of the disease. Additionally, high number of microparticles derived from platelets, red blood cells and leukocytes are also associated with chronic COPD [84, 85] (Table 1).

Multiple studies have described mononuclear/macrophage-derived EVs rich in inflammatory effector molecules like cytokines, chemokines, adhesion molecules and proteases to cause alveolar wall destruction and 
emphysema, the hallmark pathological features of COPD [113-115]. Cigarette smoke exposure causes increased release of tissue factor (TF)-positive microvesicles with high pro-coagulant activity from human macrophages [115]. These EVs also carry MMP14 that is responsible for promoting lung emphysema via its collagen degradation and gelatinolytic properties [116]. Another study described increased release of macrophage-derived EVs containing IL-8, MCP-1 and ICAM-1 pro-inflammatory molecules on the activation of monocytes by cigarette smoke exposure [114].

A recent study suggested that the COPD pathogenesis is promoted via neutrophil elastase coated exosomes released by activated but not quiescent polymorphonuclear leukocyte neutrophils. The neutrophil elastase linked to exosomes destroys the extracellular matrix proteins of the alveoli leading to the development of COPD like characteristics [117].

Chronic obstructive pulmonary disease is also characterized by endothelial cell damage due to increased apoptosis. Microparticles containing endothelial markers, such as CD31, CD62E (E-selectin), CD143, and $\mathrm{CD} 105$, are differentially released from these apoptotic endothelial cells based on the pathophysiological stage of the disease [84, 116] (Table 1). These microparticles are believed to promote progression of COPD by causing apoptosis of neighboring healthy endothelial cells upon delivery of inflammatory cargo [116]. Chronic obstructive pulmonary disease is also one of the major secondary complications that arise in human immunodeficiency virus (HIV)-infected patients [118]. Interestingly, it has recently been reported that EVs isolated from bronchoalveolar lavage (BAL) fluid of HIV-positive patients carry HIV-Nef protein that induces endothelial cell apoptosis, which may be responsible in promoting emphysema and pulmonary vascular changes observed during COPD [118]. As such, further research into the role of EVs as mediators of the chronic pulmonary complications of HIV infection appears to be well warranted.

Cigarette smoke exposure also leads to increased release of microparticles from mouse and human microvascular and pulmonary arterial endothelial cells [90]. These microparticles are enriched in ceramides and phosphatidyl serine due to high sphingomyelinase activity in endothelial cells, crucial for stress induced apoptosis [90]. These endothelial-derived microparticles (EMPs) circulate in the blood and can act as a biomarker to assess the severity of the disease condition $[90,119]$ (Table 1). Serban et al. reported a greater number of EMPs in plasma of COPD patients who were cigarette smokers as compared to healthy non-smokers [90]. These cigarette smoke-associated EMPs had high levels of miRNAs such as let-7d, miR-126, - 125-5p, and - 22 that have been known to promote angiogenesis, airway inflammation, cancer progression, cell cycle arrest, and apoptosis [90] (Fig. 2). Direct exposure of cigarette

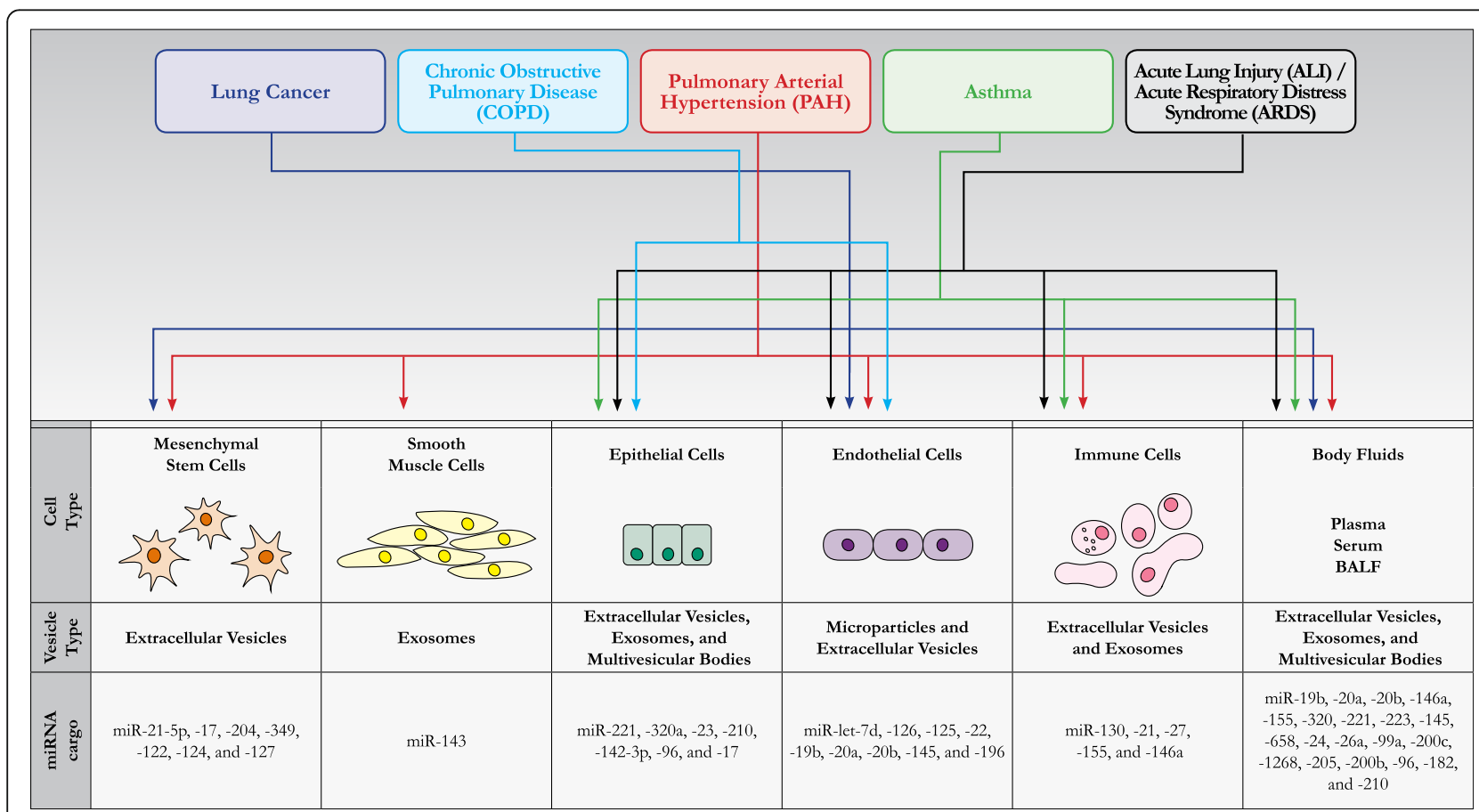

Fig. 2 Illustration showing release of various types of extracellular vesicles and their miRNA content released from different cell types/body fluids in various lung complications 
smoke on primary human microvascular endothelial cells led to release of microparticles that were reported to impair macrophage efferocytosis (clearance of apoptotic cells), thus exacerbating the inflammation and endothelial injury [90]. In another study carried out on COPD patients, the number of $\mathrm{CD} 31^{+}$EMPs suggestive of endothelial apoptosis was found to be elevated in plasma of patients with mild COPD that also exhibited emphysema [86]. Furthermore, in patients with severe COPD, CD62 ${ }^{+}$EMPs were found to be increased due to endothelial activation during severe form of disease [86]. A subsequent study elaborated on the exaggerated release of $\mathrm{CD} 31^{+}$EMPs in the plasma of cigarette smokers with COPD or no COPD, in comparison to nonsmokers [87]. As COPD patients undergo excessive levels of lung endothelial damage and persistent endothelial stress with no improvement in lung function, cessation of smoking did not change the plasma CD31 ${ }^{+}$ EMPs levels in smokers with COPD patients, whereas reduction in the release of EMPs was observed in smokers without COPD [87]. In another prospective study of COPD patients in Japan, the number of VEcadherin $\left(\mathrm{CD} 144^{+}\right)$EMPs, CD31 ${ }^{+}$EMPs, and E-selectin $\left(\mathrm{CD}^{+} 2^{+}\right)$EMPs were evaluated in blood samples and correlated with FEV over $1 \mathrm{~s}\left(\mathrm{FEV}_{1}\right)$ changes in the lung [88]. It was shown that an increase in circulating VEcadherin EMPs positively correlated with FEV decline in these patients, suggesting endothelial injury to be a prominent factor in the development of COPD [88]. In another study, increased levels of $\mathrm{CD}_{3} 1^{+}, \mathrm{CD}_{2}{ }^{+}$and CD144 ${ }^{+}$EMPs were found in the blood of COPD patients as compared to healthy controls [89]. Specifically, circulating E-selectin and VE-cadherin EMPs were found to be associated with increased exacerbation susceptibility and decline in FEV and total lung capacity in severe COPD patients [89] (Table 1). Finally, in a study by Liu et al., rats exposed to cigarette smoke for 2-6 months showed elevated levels of circulating $\mathrm{CD}^{+} 1^{+}$and CD62E+ EMPs in the blood plasma. The elevated level of EMPs was found to be proportional to lung destruction and corresponded to a decrease in pulmonary function parameters such as forced vital capacity and total lung volume [119].

In COPD induced by cigarette smoke exposure, alveolar macrophages and alveolar epithelial cells are directly exposed to the toxic components of cigarette smoke [120]. The role of lung epithelial cell-derived EVs in the pathogenesis of COPD has also been well reported [120]. Cigarette smoke exposure leads to exaggerated release of exosomes from damaged epithelial cells and promotes emphysema [120]. It has been shown that human bronchial epithelial cells (BEAS-2B) exposed to cigarette smoke demonstrate increased Rab27A-dependent release of EVs [121]. Cigarette smoke exposure in bronchial epithelial cells also stimulates release of full-length CYR61/CTGF/NOV family1 (flCCN1)-enriched EVs which mediate IL-8 induced inflammation, but also helps maintain lung homeostasis by increasing the levels of vascular endothelial growth factor (VEGF) [121]. However, prolonged cigarette smoke exposure causes cleavage of flCCN1 to form $\mathrm{CCN} 1$ in the extracellular matrix, thereby promoting the release of MMPs and reduced VEGF, causing epithelial cell damage and development of emphysema [121]. A recent study by Fujita et al. demonstrated that cigarette smoke extract induced human bronchial epithelial cell-derived EVs promote myofibroblast differentiation of the lung fibroblasts, leading to the development of fibrosis [122]. The bronchial epithelial cell-derived EVs carry miR-210 that regulates autophagy by directly targeting Atg7 [122]. Reduction in autophagy by miR-210 mediated Atg7 inhibition leads to differentiation of lung fibroblasts into myofibroblasts [122]. Furthermore, lung fibroblasts isolated from COPD patients demonstrate decreased autophagy and fibroblast differentiation [122]. Epithelialderived exosomes following cigarette smoke exposure are also known to carry pro-inflammatory cytokines and Wnt-5a that are delivered to neighboring and far away cells via circulation [120].

\section{Pulmonary hypertension (PH)}

Pulmonary hypertension is a chronic progressive disease that leads to right ventricular failure and ultimately death. The prime pathological feature of the pulmonary hypertension is vascular remodeling in lungs leading to the loss of endothelial integrity and proliferation of vascular smooth cells $[123,124]$. The resulting increase in the thickness and stiffness of blood vessels leads to chronic increase in mean pulmonary artery and right ventricular systolic pressures, ultimately resulting in right ventricular failure [123, 124]. Lately, a number of studies have demonstrated the pivotal role EVs serve in the progression and prevention of $\mathrm{PH}$, as well as useful biomarkers of the disease.

An early study published by Bakouboula et al. in 2008 showed an increase in endothelium-derived CD105 microparticles in pulmonary arterial blood from patients with pulmonary arterial hypertension (PAH) or Group 1 $\mathrm{PH}$ [98]. Another study shortly thereafter reported an increase in the levels of microparticles positive for endothelial PECAM and VE-cadherin (but not E-selectin) in the plasma samples from PAH patients compared to controls [95]. This increase in EMPs was found to be correlated with the increase in mean pulmonary arterial pressure, pulmonary vascular resistance, and mean right arterial pressure [95]. The same group later demonstrated higher number of circulating CD62e ${ }^{+}$EMPs in the plasma of $\mathrm{PH}$ patients [96] (Table 1). 
Later Diehl et al. observed that the platelet activation and inflammation during thromboembolic $\mathrm{PH}$ results in increased levels of platelet and leukocyte-derived microparticles in blood [99]. Furthermore, increased levels of circulating EMPs were observed in these patients due to enhanced endothelial apoptosis indicative of thromboembolic complications and $\mathrm{PH}$ progression [99]. Additionally, the circulating platelet- and endothelial-derived microparticles from plasma of idiopathic PAH patients (IPAH) showed the presence and increased expression of CD39 and ATPase/ADPase activity compared to those from healthy controls [91]. CD39 (ENTPD1), an ectonucleotidase responsible for extracellular dephosphorylation of ATP to ADP and AMP, leads to activation of purinergic cell signaling pathways involved in $\mathrm{PAH}$ pathogenesis [91]. Further research found increased levels of small platelet-derived microparticles (PMP) and EMPs in plasma from patients with either IPAH, heritable PAH or PAH associated with connective tissue diseases, suggesting a common phenomenon of inflammation and vascular dysfunction occurs in the progression of all forms of $\mathrm{PAH}$ [94]. Moreover, an increased level of endothelial, $\mathrm{CD} 31^{+}$derived exosomes in the plasma of patients with idiopathic PAH was also found [93] (Table 1). The study also noted an important observation that the exosomes released by human pulmonary artery endothelial cells in response to inflammation and hypoxia, when administered to human pulmonary arterial smooth muscle cells (HPASMCs), induce proliferation in these recipient cells [93]. Among the PAH patients with other complications such as transfusion-dependent $\beta$-thalassemia and hemoglobin $\mathrm{E}$ thalassemia, the presence of increased phosphatidylserine (PS)-containing red blood cell- and platelet-derived EVs were found [125].

Among the various pre-clinical animal model studies, the pathological role of EV was beautifully described in the mice model of monocrotaline-induced PAH (MCT-PAH) by Aliotta et al. They reported that the injection of lung- and plasma-derived small-sized EVs $(30-400 \mu \mathrm{m})$ isolated from the diseased mice is able to develop PAH in the healthy mice [126]. They reported increased levels of miRs-19b,-20a,-20b, and 145 known to be targeting BMPR signaling, apoptosis and cell proliferation in the exosomes from MCT mice and IPAH patients [126] (Fig. 2). In the same mice model, it was demonstrated that EVs from bone marrow, lung, and plasma reduced apoptosis of pulmonary vascular endothelial cells (PVECs) [127]. Hypoxia-induced miR-107, responsible for decreasing pro-apoptotic signal, was increased in these cells after treatment with the EVs from the PAH mice model [128]. Not only this, EVs released by PVECs from MCT-PAH mice can convert healthy bone marrow derived endothelial progenitor cells into a pathological progenitor phenotype [129]. When injected into the lungs of healthy mice, these pathological progenitors cause pulmonary vascular remodeling [129].

Circulating platelet and erythrocyte-derived MPs from hypoxic rats are known to decrease nitric oxide production and increase xanthine oxidase and mitochondrial reactive oxygen species (ROS) in pulmonary arterial endothelial cells, further contributing to their dysfunction [130]. This is executed via MP-driven reduction in endothelial nitric oxide synthase (eNOS) activity highly specific to pulmonary ECs [130]. Moreover, endoglin positive MPs from the blood of the Sugen-hypoxia rat model of severe PAH induced the expression of inflammatory adhesion molecule-1 (ICAM-1) only in pulmonary artery endothelial cells, but not pulmonary microvascular endothelial cells (PMVECs) [131]. This suggests that MPs from severe PAH contribute to pulmonary vascular lesion formation by specifically targeting pulmonary arteries [131].

Both protein and nucleic acid EV cargo have been suggested to play roles in the pathogenesis of PAH. Translationally controlled tumor protein (TCTP), known to be associated with heritable $\mathrm{PAH}$, was found to be highly expressed in exosomes released from blood outgrowth endothelial cells (BOECs) with BMPR-2 mutation, [92]. In addition, TCTP in BOEC-derived exosomes is able to get transferred to PASMCs leading to SMC proliferation [92].

Furthermore, miR-143-3p induces migration and proliferation of pulmonary arterial endothelial cells (PAECs) upon its delivery via PASMC-derived exosomes, therefore contributing to PAH [132]. In a recent study from our lab, we have shown that extracellular derived vesicles obtained from HIV-infected monocyte-derived macrophages (MDMs) exposed to drugs of abuse like cocaine are able to induce human pulmonary arterial smooth muscle cell (HPASMC) proliferation [133]. We reported that these EVs carry miR-130 that target PTEN, thereby activating PI3/AKT signaling in HPASMCs leading to hyperproliferation [133]. Furthermore, disrupted signaling between pericytes and neighboring pulmonary microvascular endothelial cells (PMVECs) suggested in $\mathrm{PAH}$ [134] was recently reported to be associated with the reduced levels of Wnt5A ligand in exosomes secreted by PMVECs in PAH patients [135]. Overall, the EVs have the ability to induce the disease phenotype in healthy cells through regulation of various pathological pathways on transfer of its cargo.

Another potential of EVs as biomarker was supported by a study demonstrating reduced levels of miR-150 in whole plasma and plasma-derived MVs of PAH patients, which were associated with reduced survival of these patients [136]. This study highlighted the utility of plasma and plasma-derived MVs miR-150 levels as potentially 
clinically useful biomarkers for PAH prognosis [136]. Rose et al. showed that endothelial cell-derived MPs can act as biomarkers for right ventricular function in $\mathrm{PAH}$ patients, wherein the number of these particles in urine was found to be increased in PAH patients compared to healthy controls [97] (Table 1). A correlation between these urine MP biomarkers and tricuspid annular plane systolic excursion (TAPSE) was observed in PAH patients [97].

\section{Asthma}

Asthma is an inflammatory disorder characterized by pulmonary obstruction and difficulty in breathing due to airway hyper responsiveness (AHR) and airway remodeling. AHR that precedes the inflammatory response [137] is characterized by abnormal narrowing of airways due to smooth muscle hypertrophy, increased angiogenesis and fibrosis [138-142]. Broadly on the basis of inflammatory trigger, asthma could be divided into two typesextrinsic/allergic and intrinsic asthma. In extrinsic asthma, the inflammatory response is usually triggered by allergens or air pollutants like smoke, dust, or pollens [143]. However, intrinsic asthma is asthma caused by anything else other than allergens and that could be due to an internal infection, stress, exercise or weather conditions [144, 145]. Also, intrinsic asthma could be more severe compared to extrinsic asthma and may not respond to the conventional therapies [146]. However, the inflammatory response is almost same in both types of asthma. Infiltration of eosinophils, mast cells, and Th2 cells in the airways and release of pro-inflammatory effector molecules like IL-4, IL-5 and IL-13 lead to prominent structural changes and remodeling of the airways [143, 147]. The lung epithelial cells, such as bronchial epithelial cells, alveolar epithelial cells, and lung fibroblasts, maintain the structure of the airway and lung homeostasis. These cells also respond to the allergens and generate an inflammatory response by releasing cytokines that further contribute to the progression of asthma [148, 149]. This response, including secretion of IL-6, also triggers the proliferation of smooth muscle cells in the airways that causes pulmonary obstruction in asthma [150]. One of the major reasons for severe asthma are Th17 cell types which differentiate from naive $\mathrm{CD}^{+}$cells on stimulation with IL-1 $\beta$, IL-23, TGF$\beta$, and IL-6 [151-154]. Th17 cells release IL-17 and other cytokines and chemokines reported to be present in the BALF fluid of severe and moderate asthma patients $[155,156]$. Binding of IL-17A on airway epithelial cells lead to release of chemokine CXCL8 (IL-8) and colony stimulatory factors (CSF), which further recruit and activate neutrophils thus increasing inflammation in the airway [151, 154, 157]. In addition, IL-17A also acts on endothelial cells and fibroblast to secrete the IL-1 $\beta$ and
IL-6 for neutrophil recruitment [158]. Additionally, IL$17 \mathrm{~F}$ act on fibroblasts and increase the expression of smooth muscle actin, thereby contributing to the remodeling of airways [153, 154]. Although severe asthma is caused by both Th2 and Th17, it is the Th17 mediated pathology which is mainly unresponsive to corticosteroid therapy $[159,160]$. Recent reports suggest that EVs released by all these cell types in lungs are involved in airway inflammation and may be involved in allergic reactions through paracrine secretions [102, 161-174]. Pathogenic effect of EVs derived from Staphylococcus aureus that is present in house dust, was shown to stimulate Toll-like receptor- 2 dependent Th1 and Th17 induced airway inflammation and augment the hypersensitivity response to the inhaled ovalbumin allergen [175].

Extracellular vesicles released from B-lymphocytes carry major histocompatibility complex (MHC) co-stimulatory molecules, antigenic peptides, [167] and HSP70 [176] which trigger inflammatory $\mathrm{T}$ cell responses. These EVs can also stimulate antigen-presenting cells to generate immune response by releasing Th2 inflammatory cytokines that contribute to AHR, critical to the development of asthma [167, 177]. Proteomic analysis of exosomes derived from LPS-stimulated and unstimulated equine neutrophils suggested presence of proteins known to play various roles in innate immunity, immune regulation, metabolism, and membrane trafficking [178]. These analyses also revealed the presence of chaperone proteins known to be associated with asthma remodeling [178]. Neutrophil-derived exosomes were reported to be internalized into pulmonary smooth cells and release bioeffector molecules that lead to their proliferation and promote airway remodeling and asthmatic progression [178].

Eosinophil-derived EVs have been shown to be released in high amounts in asthma patients that may be involved in airway inflammation [100] (Table 1). These EVs carry various proinflammatory molecules such as interleukins, chemokines, chemotoxins like RANTES and eotaxin-1, prostaglandins, and platelet activating factors that are known to promote AHR and asthma pathogenesis [162, 179, 180]. Another study demonstrated that eosinophil-derived exosomes from the blood of asthma patients induced apoptosis in primary alveolar epithelial cells at $24 \mathrm{~h}$ and $48 \mathrm{~h}$ of exposure, via reduction in JAK/STAT signaling, and stimulating the release of inflammatory mediators like TNF and CCL26 [101]. However, on further exposure, these EVs promote epithelial proliferation by activating PI3/AKT signaling [101]. Furthermore, eosinophil-derived EVs induce proliferation of bronchial smooth muscle cells and increase VEGF-A and CCR3 expression in these cells through activation of ERK1/2 signaling, thus contributing to the fibrosis and remodeling observed in asthma [101]. 
Extracellular vesicles released from alveolar epithelial cells are reported to be higher in asthmatic mice as compared to control mice [164]. In animal models, lung epithelial cell-derived exosomes enhance the infiltration of macrophages and production of IL-13, leading to the development of asthma [164]. Another study demonstrated that human tracheobronchial epithelial cells change their protein and miRNA expression pattern after the uptake of exosomes from alveolar epithelial cells with asthma pathology, and may be responsible for higher mucin secretion and airway remodeling [181]. The EVs isolated from bronchial alveolar lavage fluid (BALF) have been widely studied for its role in asthma. The role of BALF EVs in the pathogenesis of asthma and allergic diseases was first reported by Admyre et al. [182]. In BALF from asthma patients, there is an increased production of EVs that directly correlates with increased HLA-DR expression responsible for immune activation of lung cells during the disease [102, 104] (Table 1). These exosomes have also been demonstrated to carry high levels of functional proteins involved in leukotriene production [102]. Additionally, an increased level of BALF EVs among asthmatics is positively correlated with eosinophil and IgE levels in blood along with more CD54 ${ }^{+}$EVs for cell adhesion [104]. Further, when these BALF exosomes were exposed to bronchial epithelial cells, they induced production of IL-8 and leukotrienes, potent proinflammatory mediators in the recipient cells [102]. Another study showed that exosomes isolated from BALF of asthmatic patients were positive for tissue factor VIII, an important factor that plays role in coagulation and promoting angiogenesis [183].

Circulating EVs from BALF and plasma may also carry miRNA cargo that may be contributing to the pathogenesis of asthma and also could serve as biomarkers for the disease [184]. A study from Sweden characterized miRNA content of the exosomes isolated from the BALF of asthma patients [185]. These investigators found alteration in the levels of 18 miRNAs in asthma patients when compared with healthy controls, out of which 8 miRNAs (let-7a, miRNA-21, miRNA-658, miRNA-24, miRNA-26a, miRNA-99a, miRNA-200c, and miRNA1268) showed significant alteration in expression [185] (Fig. 2). A strong correlation was observed between the expression profile of these altered miRNAs and FEV1 within the asthmatic patient group [185]. Let-7 family miRNAs have been shown to be influential in respiratory inflammation and AHR through regulation of IL-13 secretion. Using an established murine model of allergic airway inflammation, Kumar et al. showed significant reductions in let-7 miRNAs in allergic inflammation lungs compared to healthy controls. After uptake by let-7 miRNAs in the murine lung, significant reductions in IL-13 levels were observed in tissue, BALF, and serum. This correlated with a significant reduction in AHR in response to methacholine [186]. Therefore, let-7-miRNAs delivered via EVs may serve as a potential therapeutic strategy for AHR in asthma that warrants further research. MicroRNA-21 has been shown to be induced by IL-13, which is critically responsible for airway hyperreactivity, in the ovalbumin (OVA) murine model of asthma [187, 188]. MicroRNA-21 also contributes to polarization of helper $\mathrm{T}$ cells toward a Th2 phenotype, further supporting the important role of miR-21 in the hyperinflammation characteristic of asthma [187]. Given the influence of miR-21 in AHR and the pathogenesis of asthma, future exploration of the role of exosomal miR21 as a biomarker for disease and FEV1 decline is warranted [187, 189, 190]. MicroRNA-140-3p is an important regulator of expression of chemokines and CD38, and appears to play an influential role in airway smooth muscle cell hyperplasia [191-193]. Circulating exosomes of patients with severe asthma exhibit significant upregulation in miR-140-3p compared to patients with mild-tomoderate asthma and healthy controls, suggesting that this miRNA may serve as an important prognostic biomarker. This study also demonstrated upregulation in miR-128, miR-196b-5p, and miR-486-5p in severe asthma patients, although the functional role of these miRNAs in the pathogenesis of asthma has not yet been elucidated [194].

Recent study signifies the role of functional mitochondria transfer via exosomes between different cell types in the disease pathogenesis [103]. Hough et al. reported the presence of mitochondria in the EVs from Bal fluid and from MHC class II cell surface receptor positive (HLA$\mathrm{DR}^{+}$) myeloid-derived regulatory cells. The HLA-DR EVs isolated from asthmatic patients had increased number of mitochondria and more amount of mitochondrial DNA within its cargo. Additionally, uptake of these mitochondria carrying EVs by $\mathrm{CD}^{+} \mathrm{T}$ cells resulted in the generation of ROS and increased $\mathrm{T}$ cell proliferation.

\section{Lung cancer}

Extracellular vesicles have been implicated in mediating intercellular communication responsible for lung carcinogenesis. Lung cancer is divided into two broad categories - small cell lung cancer (SCLC) and non-small cell lung cancer (NSCLC). The NSCLC is further divided to 3 subtypes: adenocarcinoma, squamous cell carcinoma, and large cell carcinoma [195]. The major reasons for development of lung cancer are smoking [196], genetic factors [197], toxic/carcinogen/environmental pollutants exposure (such as dust, asbestos), gender [198], and diet [199]. In addition, various types of bacterial and viral infections including $\mathrm{HIV}-1$ and HPV can lead to the development of lung cancer [200, 201]. 
The EVs may contribute to various cellular functions, including epithelial-mesenchymal transition, angiogenesis, tumorigenesis and metastasis associated with lung cancer [202, 203]. Further, exosome secretion and release within the tumor microenvironment changes the levels of cytokines and growth factors such as TGF- $\beta$, IL-10, IL-6, MCP-1 by activation of proliferative signaling cascades like MAP kinases and NF-KB pathways and are therefore instrumental in promoting lung tumor progression and metastasis [204-206]. Exosomes released from metastatic small cell lung cancer cells carry increased amounts of TGF- $\beta$ and IL-10 and are able to induce cancer cell proliferation and migration [205]. Tumor microenvironment derived exosomes also reprogram the metabolic machinery to provide metabolites like amino acids, lipids, and respiratory cycle intermediates that can be utilized by cancer cells for their growth and metabolism under nutrient-stress conditions [207]. Rab27a facilitates exosomes in carrying proinflammatory cytokines and matrix metalloproteinases (MMPs) responsible for tumor progression and cancer cell metastasis [208]. Microvesicles derived from activated platelets can also cause metastasis of lung carcinoma. Additionally, exosomes have been shown to carry enzymes which can synthesize their respective products in the recipient cells and modify the cellular phenotype [209]. The exosomes from the pleura exudates of lung cancer patients showed the presence of leukotriene synthesizing enzyme $\gamma$-glutamyl transpeptidase- 1 which synthesizes the pro- tumorigenic LTD4 leukotriene from LTC4 produced by monocytes to support cell survival and migration of tumor cells [209]. Platelet-derived MVs contain integrin and matrix metalloproteinases that cause hyperproliferation and enhanced migration of lung cells, along with increased expression of angiogenic factors such as VEGF, MMP-9, and IL-8 [210]. These MVs also lead to increase in metastasis and angiogenesis in human syngeneic mice [210]. Platelet-derived MVs from lung cancer patients are also able to induce metastasis and promote tumor cell invasion by delivering miR-223 that targets tumor suppressor gene EPB41L3 (erythrocyte membrane protein band 4.1-like 3) [210]. Via mRNA and miRNA, cargo of exosomes derived from lung cancer cells can also stimulate the normal lung cells to undergo epithelial-to-mesenchymal transition [105] and induce migration and proliferation [206, 211]. Tumor cell-derived exosomes have been reported to contain hTERT mRNA responsible for increased telomerase activity within cells that causes uncontrolled cell growth and malignancy [212]. This hTERT mRNA gets transported via exosomes to non-cancer cells where it induces cell proliferation and delayed senescence, producing cancer-like characteristics [212]. Interestingly, HIV-derived transactivation response element (TAR)
RNA has been known to activate proto-oncogenes and TLR3 inducible genes, promote tumor growth and cancer cell progression [213]. It was observed that exosomes from HIV-infected T cells carrying HIV TAR RNA enter lung cancer cells through epidermal growth factor receptor (EGFR), stimulating cell proliferation and migration through activation of the ERK1/2 signaling pathway [213].

Exosomes derived from neoplastic transformed umbilical vein endothelial cells can transfer miR-21 to normal cells and lead to increased angiogenesis and malignant transformation through increased activation of STAT3 signaling and VEGF levels [214]. miR21-5p also inhibits PTEN in lung cancer cells to activate AKT signaling pathway and promote tumor cell growth, cell proliferation, and epithelial-mesenchymal transition [215]. Exosomal miR-21 and miR-155 have been reported to be more highly expressed in recurring lung cancer tumors than primary tumors, suggesting that specific miRNA signatures in exosomes derived from serum of lung cancer patients can serve as biomarkers for diagnosis of disease [215]. Hypoxic lung cancer cell-derived exosomes carry high levels of miR-23 that targets prolyl hydroxylase and zona occludens- 1 in endothelial cells [216]. Disruption of tight junction proteins induces vascular permeability, angiogenesis and trans-endothelial migration of cancer cells [216]. Tumor-derived exosomes induce differentiation of fibroblasts to tumor-promoting stromal fibroblasts by activation of TGF- $\beta$ signaling [217]. However, another study found that lung adenocarcinoma cell-derived EVs deliver miR-142-3p to endothelial cells to promote angiogenesis, cell proliferation and differentiate fibroblasts to cancer-associated phenotype, independent of TGF- $\beta$ signaling [218] (Fig. 2). Notably, EVs derived from the fluid of pleural effusions in lung cancer patients also exhibit alterations in miRNA cargo [218]. One study reported the presence of miR205-5p and miR-200b in high amounts in lung cancer patients [219]. Another study demonstrated that patients with malignant lung adenocarcinoma have high circulating levels of miR-182 and miR-210 in pleural effusion, which is noticeably absent in benign lung cancers suggesting an involvement in lung cancer progression [220]. Serum-derived EVs from high-grade malignant lung cancer patients have high expression of miR-96, a tumor promoter [221]. MiR-96 mainly acts by targeting LIMdomain only protein 7 (LMO7) protein that helps in maintaining alveolar architecture, actin cytoskeleton and functions as tumor suppressor in lung cancer [221].

In addition to miRNA cargo, long non-coding (lnc) RNAs are also carried by EVs which may contribute to lung cancer progression and tumorigenesis. The lncRNA MALAT-1 (metastasis associated lung adenocarcinoma transcript-1) is found to be highly up-regulated in the exosomes derived from serum of lung cancer patients 
and expression is also correlated with the metastatic stage [106] (Table 1). MALAT-1 was also able to prevent lung cancer cell apoptosis, alternatively leading to proliferation, cell migration and invasion [106]. LncRNA H19 is highly expressed in geftinib- resistant lung cancer cells and gets packaged into their exosomes [222]. Geftinib is a tyrosine kinase inhibitor used as a therapy for highly malignant non-small cell lung cancer (NSCLC) and geftinib-resistance is one of the major obstacles in its treatment [222]. In this study, it was shown that lncRNA H19 is delivered to non-resistant cells via exosomes and able to confer geftinib-resistance [222].

\section{Acute lung injury (ALI), acute respiratory distress syndrome (ARDS), and pulmonary Sepsis}

Acute lung injury (ALI) and acute respiratory distress syndrome (ARDS) is characterized by inflammation and disruption of the endothelial and epithelial barriers of the lung, leading to acute respiratory failure and a very high mortality rate [223]. The most common cause of ALI and ARDS is sepsis secondary to pulmonary infection [224]. Lately, there has been a profound increase in reports demonstrating the influential role of EVs in sepsis-induced and non-sepsis-induced ALI and ARDS. Leukocyte-derived MPs circulating in BALF and blood of ARDS patients appear to be associated with patient survival [107] (Table 1). Additionally, endothelial cellderived MPs have also shown promise as biomarkers and mediators of ALI and ventilator-induced lung injury (VILI) [107]. In vitro and in vivo studies have shown increased release of endothelial-derived microparticles (EMPs) representative of cellular dysfunction, after exposure to mechanical stress and endotoxin characteristic of Gram-negative bacterial infection [225]. Mechanical stress-derived EMPs were also able to develop inflammation and injury in lungs when injected in healthy mice [225]. These EMPs have been reported to be released by endothelial cells during ALI due to defects in cytoskeleton. Their increased levels were induced by external or internal stimuli such as LPS which corresponded to the decline in the surface area of plasma membrane and cell volume, enlarging the intercellular gaps and junctions [226]. Another study showed that IFN- $\alpha$ induced pulmonary injury resulted in an increase in the number of circulating EMPs in the blood, leading to cytoskeleton rearrangement and endothelial cell apoptosis [227]. This was prevented by inhibition of Rho-kinase activity and targeting EMPs may be useful as well [227]. In an ARDS rat model, $\mathrm{Li}$ et al. found no difference in total blood MPs versus controls; however, the concentration of leukocyte- and endothelium- derived MPs was higher in ARDS, further demonstrating their influential role in the pathogenesis of ARDS [228].
Encapsulated caspase-1 in monocyte-secreted MPs is able to induce apoptosis of human pulmonary microvascular endothelial cell (HPMVEC) in ALI/ARDS [108, 229]. These findings are in agreement with other reports on traumatic brain injury (TBI) induced ALI/ARDS, where higher levels of ASC (apoptosis-associated specklike protein containing a caspase-recruiting domain) in the serum EVs led to the pyropotosis of endothelial cells via activation of inflammasomes [109] [230]. EMPs have also been shown to initiate a cascade of pulmonary and systemic proinflammatory molecules leading to the development of lung injury [231]. EVs released by lung epithelial cells in the hyperoxia-induced ALI (HALI) animal model were found to activate alveolar macrophages to induce proinflammatory response in lung tissue upon delivery of caspase-3 [232]. Another study showed the role of MVs from BALF and lung epithelial cell-culture media in HALI with significant alterations in the levels of miR-320a and miR-221 responsible for proinflammatory response via macrophage activation [233] (Fig. 2). Studies involving LPS-induced ALI showed the rapid production of pro-inflammatory MVs and exosomes by lung macrophages, leading to lung injury [234, 235]. Also, endothelial and leukocyte-derived MPs in blood from LPS-treated rats were shown to induce a proinflammatory response and ARDS in healthy rats [236, 237].

In influenza virus-induced ALI, EVs have been shown to suppress antiviral factor and promote replication of influenza virus through a miRNA-mediated mechanism in lung epithelial cells [238]. In acid-induced ALI, the elevated levels of miR-17 and 221 in lung epitheliumderived MVs were found to be involved in the activation and recruitment of macrophages [239]. Both sterile stimuli (oxidative stress or acid aspiration) and infection (LPS/ Gram-negative bacteria) lead to increase in BALF EVs, however, the source for these EVs differed [240]. BALF EVs from sterile stimuli was mainly from alveolar type-I epithelial cells, whereas infection-induced BALF EVs were from alveolar macrophages (AMs). Nonetheless, both kinds of EVs generated same kind of functional response by promoting macrophage recruitment and generation of inflammatory cascade in the lungs [240].

In addition to the pathways previously reviewed, aberrations in coagulation and fibrinolysis also play pivotal roles in inducing inflammatory responses in ALI and ARDS. Tissue factor (TF), an initiator of the coagulation cascade, is detected in high levels in patients' lungs and can cause deposition of fibrin in airspace [110]. MPs containing TF are released by alveolar epithelium in response to proinflammatory stimulus in ALI/ARDS lungs, therefore contributing to coagulation [110] (Table 1).

Most studies analyzing EVs in patients with sepsis have included those with undifferentiated sepsis due to 
multiple potential sources, making generalizability of findings specific to pulmonary sepsis difficult. There is some evidence to indicate differences in EV cargo exist based on source of underlying sepsis. Researchers have shown that plasma-derived MVs from patients with sepsis due to community-acquired pneumonia (CAP) have higher expression of alpha-2-macroglobuin compared to patients with sepsis due to fecal peritonitis [111]. Furthermore, they demonstrated an association between higher plasma alpha-2-macroglobulin positive MVs and survival in patients with CAP [111]. This was consistent with previous findings from the same group, in which granulocyte-derived EVs carrying alpha-2-macroglobulin were protective in patients with sepsis due to CAP [112] (Table 1). These results are noteworthy in consideration of the fact that the cecal ligation and puncture (CLP) model is commonly used as a mouse model of sepsis [241]. Results generated from CLP models may not be generalizability to non-peritonitis subsets of sepsis, including sepsis secondary to lung infections. Further research on the dynamics of circulating EVs in patients with sepsis and evaluation of differences based on source of infection and causative pathogen are warranted.

\section{Therapeutic potential of EVs in lung diseases}

Though EVs are implicated in the pathogenesis of the pulmonary complications, as we have reviewed; EVs also may serve in a role as potential therapeutic agents (Table 2) [161, 206, 261, 262]. Mesenchymal stem cells (MSC) and the products released from these cells such as MSC-derived extracellular vesicles (MSC-EVs) are being explored for their protective capabilities against lung diseases [262-264].

\section{COPD/asthma}

When administered to activated alveolar macrophages, MSC-EVs lead to reduction in the release of proinflammatory molecules, decrease the infiltration of neutrophils and lymphocytes in the BALF and airways, and contribute to reducing the collagen content in the lung parenchyma [253, 254, 263]. Overall, this leads to a protective effect against lung disease like COPD and ALI [253, 254, 263]. Moreover, MSC-EVs are able to transfer mitochondria to alveolar epithelial cells and macrophages to overcome oxidative stress characteristic of lung diseases like COPD and ALI [253, 254].

MSC-derived EVs have been shown to exert immunomodulatory effects on PBMCs, including release of IL-10 and TGF- $\beta$, stimulating proliferation of T regulatory cells (Tregs) and leading to immune suppression in asthmatic patients [246]. Adipose tissue derived-mesenchymal stem cells EVs (AD-MSC) reduce eosinophilic infiltration into the lung tissue and parenchymal collagen content in mouse models of asthma [247]. MSC-derived EVs have also been found to abrogate inflammatory response by increasing anti-inflammatory IL-10 and reducing Th2 and Th17 associated cytokines [248]. Kim et al. prepared ADMSC-derived artificial nanovesicles that expressed similar AD-MSC surface markers and growth factors such as FGF2, important in lung regeneration [22]. These nanovesicles were able to induce epithelial cell proliferation via FGF2-dependent pathway and inhibit emphysema in mice model [22].Mast-cell derived exosomes exhibit Fc $\xi R 1$ receptors that trap free IgE and limit the effects of mast-cell activation during asthma [172]. Another study showed protective effects of EVs from human bone marrow derived mesenchymal stem cells in preventing the development of AHR, pulmonary inflammation and Th2 and Th17 antigen dependent activity in the allergic response to Aspergillus hyphal extract in immunocompetent mice [248]. The therapeutic utility of human mesenchymal stromal cells derived small EVs in reducing allergic airway asthma was also demonstrated by their ability to lower the levels of group 2 innate lymphoid cells (ILC2s), reduce AHR and infiltration of inflammatory cells with decrease in the levels of Th2 cytokines and mucus production in lungs [250]. Furthermore, the inhibitory effect of exosomes isolated from Pseudomonas aeruginosa on the development of AHR along with reduced inflammation in the perivascular and peribronchial spaces in allergic asthma model has also been reported. This inhibitory effect was attributed to the increased Treg and attenuated Th2 responses on treatment with $P$. aeruginosa derived exosomes [249].

\section{$\mathrm{PH}$}

Mesenchymal stromal cell-derived exosomes were able to cause reduction in right ventricle systolic pressure and vascular remodeling in a mouse model of hypoxia$\mathrm{PAH}$ by inhibiting induction of proinflammatory and pro-proliferative mediators and macrophage influx by suppressing the hypoxic activation of STAT3 and miR17 super family [242]. In addition, these exosomes increased the expression of anti-proliferative miR-204 in lungs of PAH mice [242]. Similarly, MSC-derived MVs were able to ameliorate $\mathrm{PAH}$ in the MCT-PAH rat model via reduction in right ventricular hypertrophy, mean right ventricular and mean pulmonary arterial pressures, and decreased pulmonary arteriole remodeling [243]. Mesenchymal stromal cells were able to promote the mitochondrial function and led to increased expression of pyruvate dehydrogenase (PDH) and glutamate dehydrogenase 1 (GLUD1), thus promoting the citric acid cycle in pulmonary smooth muscle cells [265]. When injected to MCT-PAH mice, MSC-exosomes reduced and reverted PAH complications [126]. These exosomes were rich in anti-inflammatory, anti-apoptotic, and anti-proliferative miRNAs such as miR $-34 a,-122$, 
Table 2 Therapeutic role of extracellular vesicles in various lung complications

\begin{tabular}{|c|c|c|c|c|c|}
\hline Disease & EV source & EV type & Cargo molecule (s) & Major effects /role & Ref. \\
\hline COPD & $\begin{array}{l}\text { Adipose-derived stem } \\
\text { cells }\end{array}$ & $\begin{array}{l}\text { Artificial } \\
\text { nano- } \\
\text { vesicles }\end{array}$ & FGF2 & $\begin{array}{l}\text { Increase in epithelial cell proliferation, inhibition of emphysema and } \\
\text { regeneration of damaged lung of mice }\end{array}$ & [22] \\
\hline \multirow[t]{6}{*}{$\mathrm{PH}$} & $\begin{array}{l}\text { Mesenchymal stromal } \\
\text { cell }\end{array}$ & Exosomes & - & $\begin{array}{l}\text { Reduction in vascular remodeling and hypoxic PH, inhibition of pro- } \\
\text { proliferative STAT3 signaling in pulmonary arterial endothelial cells }\end{array}$ & [242] \\
\hline & Mesenchymal Stem Cells & MVs & - & $\begin{array}{l}\text { Reduction in mean pulmonary arterial pressures, right ventricle } \\
\text { hypertrophy in monocrotaline-PH rat model }\end{array}$ & [243] \\
\hline & $\begin{array}{l}\text { Mesenchymal stromal } \\
\text { cell }\end{array}$ & Exosomes & - & $\begin{array}{l}\text { Promoted mitochondrial function and TCA cycle in pulmonary artery } \\
\text { smooth muscle cells }\end{array}$ & [244] \\
\hline & Mesenchymal Stem Cells & Exosomes & $\begin{array}{l}\text { miRs-34a, }-122 \\
-124, \text { and }-127\end{array}$ & Reversed PH in monocrotaline mice model & [126] \\
\hline & Mesenchymal Stem Cells & EVs & - & $\begin{array}{l}\text { Reversal of bone marrow endothelial progenitor cells (EPCs) mediated } \\
\text { PAH }\end{array}$ & [129] \\
\hline & Endothelial cells & MPs & Endoglin & Improved survival and proliferation of pulmonary endothelial cells & [245] \\
\hline \multirow[t]{7}{*}{ Asthma } & Mesenchymal Stem Cells & Exosomes & - & $\begin{array}{l}\text { Promoted proliferation and immune-suppression capacity of T regula- } \\
\text { tory cells }\end{array}$ & [246] \\
\hline & $\begin{array}{l}\text { Adipose derived } \\
\text { Mesenchymal Stem Cells }\end{array}$ & EVs & - & $\begin{array}{l}\text { Reduced airway remodeling and eosinophil counts in lung tissue and } \\
\text { BALF of ovalbumin mice. }\end{array}$ & [247] \\
\hline & $\begin{array}{l}\text { Mesenchymal stromal } \\
\text { cells }\end{array}$ & EVs & - & $\begin{array}{l}\text { Abrogated inflammatory response by increasing } \mathrm{IL}-10 \text { and reducing } \\
\text { Th2 and Th17 associated cytokines in the mice model of asthma }\end{array}$ & [248] \\
\hline & $\begin{array}{l}\text { Bone marrow derived } \\
\text { mast cells }\end{array}$ & Exosomes & IgE receptors (Fc६R1) & $\begin{array}{l}\text { Reduced lgE levels and mast cell activation in allergic asthma mouse } \\
\text { model }\end{array}$ & [172] \\
\hline & $\begin{array}{l}\text { Human bone marrow } \\
\text { derived mesenchymal } \\
\text { stem cells }\end{array}$ & EVs & - & $\begin{array}{l}\text { Prevent development of airway hyper responsiveness and pulmonary } \\
\text { inflammation in response to allergen }\end{array}$ & [248] \\
\hline & Pseudomonas aeruginosa & Exosomes & - & $\begin{array}{l}\text { Prevention of allergic reactions by increasingTreg and decreasing the } \\
\text { Th2 response. }\end{array}$ & [249] \\
\hline & $\begin{array}{l}\text { Human mesenchymal } \\
\text { stromal cells }\end{array}$ & Small EVs & miR-146a-5p & $\begin{array}{l}\text { Reduction in the infiltration of inflammatory cells, Th2 cytokines and } \\
\text { airway hyperresponsiveness }\end{array}$ & [250] \\
\hline $\begin{array}{l}\text { Lung } \\
\text { Cancer }\end{array}$ & $\begin{array}{l}\text { Dendritic cell derived } \\
\text { exosomes (DEX) }\end{array}$ & Exosomes & MAGE tumor antigen & $\begin{array}{l}\text { Modest stabilization of NSCLC patients in response to DEX } \\
\text { immunotherapy }\end{array}$ & [251] \\
\hline \multirow[t]{9}{*}{$\begin{array}{l}\text { ALI/ } \\
\text { ARDS }\end{array}$} & Mesenchymal Stem Cells & MVs & $\begin{array}{l}\text { Keratinocyte Growth } \\
\text { Factor mRNA }\end{array}$ & $\begin{array}{l}\text { Reduction in pulmonary edema and influx of inflammatory cells in } \\
\text { BAL of } E \text {. coli endotoxin -induced ALI mice; }\end{array}$ & [252] \\
\hline & Mesenchymal Stem Cells & $\begin{array}{l}\text { Exosomes/ } \\
\text { MVs }\end{array}$ & $\begin{array}{l}\text { Mitochondria/ } \\
\text { miRNA }\end{array}$ & $\begin{array}{l}\text { MSC-MVs transfer depolarized mitochondria to macrophages and } \\
\text { increase macrophage bioenergetics; MSC-exosomes modulate TLR } \\
\text { signaling and cytokine release in macrophages }\end{array}$ & [253] \\
\hline & $\begin{array}{l}\text { Mesenchymal stromal } \\
\text { cells }\end{array}$ & EVs & Mitochondria & $\begin{array}{l}\text { Reduced inflammation and lung injury; enhanced oxidative } \\
\text { phosphorylation in macrophages }\end{array}$ & [254] \\
\hline & Mesenchymal Stem Cells & EVs & Runx1 p66 and p52 & $\begin{array}{l}\text { Enhanced junctional integrity of injured endothelial cells and } \\
\text { decreased lung pathology }\end{array}$ & [255] \\
\hline & Mesenchymal Stem Cells & EVs & - & $\begin{array}{l}\text { Modulated cytoskeletal signaling in endothelial cells and attenuated } \\
\text { lung vascular permeability }\end{array}$ & [256] \\
\hline & Mesenchymal Stem Cells & MVs & - & $\begin{array}{l}\text { Increased alveolar fluid clearance and reduced protein permeability } \\
\text { and inflammation; increased antimicrobial in ex-vivo perfused human } \\
\text { lung model of bacterial pneumonia }\end{array}$ & [257] \\
\hline & $\begin{array}{l}\text { Umbilical cord } \\
\text { mesenchymal stromal } \\
\text { cells }\end{array}$ & Exosomes & $\begin{array}{l}\text { Angiopoietin } 1 \text { and } \\
\text { hepatocyte growth } \\
\text { factor }\end{array}$ & $\begin{array}{l}\text { Restoring alveolar fluid clearance and protein permeability of } \\
\text { influenza virus infected alveolar epithelial cells }\end{array}$ & [258] \\
\hline & $\begin{array}{l}\text { Endothelial progenitor } \\
\text { cells }\end{array}$ & Exosomes & miR-126 & $\begin{array}{l}\text { Enhanced proliferation, migration of endothelial cells by promoting } \\
\text { RAF/ERK signaling, ameliorated LPS-induced lung injury }\end{array}$ & [259] \\
\hline & $\begin{array}{l}\text { Inducible pluripotent } \\
\text { stem cells }\end{array}$ & Exosomes & $\begin{array}{l}\text { siRNAs against ICAM- } \\
1\end{array}$ & $\begin{array}{l}\text { Successfully delivered siRNA into HMVECS and inhibited expression of } \\
\text { ICAM-1 and neutrophil adhesion }\end{array}$ & [260] \\
\hline
\end{tabular}


- 124, and-127 [126]. MSC-derived EVs have also shown to reverse the effect of endothelial progenitor cells from $\mathrm{PAH}$ mice in developing $\mathrm{PAH}$ in healthy mice [129]. Increased levels of circulating endoglin+ endothelial MPs in the plasma of chronic thromboembolic pulmonary hypertension (CTEPH) patients improved the survival and proliferation of recipient cultured primary human pulmonary endothelial cells, thus demonstrating a therapeutic role of these particles [245]. Apart from MSCs, delivery of miR-195 to SMCs via endothelialderived exosomes was reported to prevent SMC proliferation and migration by inhibiting the expression of serotonin transporters and thus may play a protective role in PAH [266].

\section{Lung Cancer}

Exosomes isolated from dendritic cells called dexosomes have successfully covered the journey from the animal models in laboratory to patient bedside as an immune system amplifying tool to treat NSCLC. The isolation of dexosomes from patient blood and then loading them with antigens, MHC I and II molecules and readministration to patients has proved to be a successful way to stimulate naive dendritic cells (DCs) in patients and boost up both innate and adaptive immune system in fighting lung and other cancers [251, 267, 268]. In addition, loading them with $\mathrm{B}$ and $\mathrm{T}$ cell epitopes enhances their immunogenicity [269]. Circulating tumor EVs can also potentially act as carriers of anti-tumor drugs, small interfering RNAs, and molecules like antiprogrammed cell death receptor 1 (PD-1) and antiprogrammed cell death ligand 1 (PD-L1) to prevent lung cancer progression [270].

\section{ALI/ARDS/pulmonary Sepsis}

MSC-derived EVs from ARDS patients showed the presence of transforming growth factor-beta receptor I (T/RI)/Alk5 and the Runx1 p66 and p52 transcription factor that are crucial in protecting ARDS [255]. Importantly, higher Runx1p66/p52 ratio provided a survival advantage [255]. Runx1p66 from bone marrow-derived MSC-EVs induces proliferation of LPS-treated ECs and help to improve pathology of lung in LPS induced ALI mice [255]. Bone marrow-derived mesenchymal stem cell EVs induced cytoskeletal RhoA GTPase activity, leading to a significant decrease in hemorrhagic shockinduced lung vascular permeability in the hemorrhagicshock mice model of ARDS [256]. Human MSC-derived EVs were also able to ameliorate ALI secondary to $E$. coli bacterial pneumonia by reducing lung protein permeability and pulmonary edema and improving alveolar fluid clearance, leading to a reduction in both bacterial load and median pulmonary artery pressure [257]. In addition, umbilical cord mesenchymal stromal cell- derived exosomes were found to suppress influenza virus-induced ALI by improving the clearance of alveolar fluid and protein permeability of $\mathrm{A}(\mathrm{H} 5 \mathrm{~N} 1)$-infected human alveolar epithelial cells [258]. Another report demonstrated transfer of functional mitochondria by MSC derived EVs to the recipient macrophages [254]. These CD44 expressing MSC-derived EVs acted as a successful therapy in the LPS model of lung injury by suppressing cytokine production, inducing antiinflammatory response, and reducing lung pathology through enhanced oxidative phosphorylation in macrophages [254]. Exosomes released from endothelial progenitor cells (EPCs) have also been reported to improve the injury in LPS-induced ALI rat model by regulating integrity, migration, and proliferation of ECs. EPC exosomes mediated transfer of miR-126 to ECs targeting the expression of SPRED1 and enhancing RAF/ERK signaling pathways were primarily responsible for restoring lung health in this model [259]. Human-induced pluripotent stem cell-derived exosomes have been used as delivery systems for siRNAs targeting ICAM-1 in human primary pulmonary microvascular endothelial cells (HMVECs), leading to obstruction of ICAM-1 protein expression and inhibition of neutrophils-endothelium adhesion induced by LPS, the primary features of ALI [260].

\section{Summary}

In conclusion, EVs are emerging as vital components of multiple pulmonary pathologies. It is highly apparent that EVs represent a heterogeneous population that differs substantially in composition and its cargo. Most of the studies included in this review investigated the role of miRNA cargo in the lung pathogenesis related to the respective diseases (Fig. 2), however the role of other small non-coding RNAs needs equal attention and should be the focus of future investigations. Additionally, various other EV content such as proteins, cytokines, enzymes are equally important to be explored further. The study of EVs is a rapidly evolving field and there remains a lack of uniformity in methods used to isolate and categorize EVs. Inconsistencies across studies may substantially influence results, which limit the generalizability of any individual study. Standardization of these methods and validation of findings in multiple prospective longitudinal cohorts is essential for the field to continue to move forward and positively impact patient care. Furthermore, pulmonary diseases are physiologically complex and occur on a spectrum of severity, which adds an additional layer of difficulty to generalize the findings from these studies. For example, there are many subtypes of lung cancer that differ in underlying molecular pathology, treatment, and prognosis [271]. This heterogeneity is true for nearly all pulmonary diseases and future investigations evaluating 
EVs as biomarkers and therapeutics should clearly account for these differences. Despite these limitations, further identification of EVs and corresponding cargo has the potential to aid in the discovery of clinically useful biomarkers and the development of novel therapeutics for lung pathologies. This promising area of research should provide some hope to the millions of patients suffering from lung diseases which are currently incurable by today's standard of care.

\section{Abbreviations}

EVs: Extracellular Vesicles; COPD: Chronic Obstructive Pulmonary Disease; ALI: Acute Lung Injury; ARDS: Acute Respiratory Distress Syndrome; MVB: Multivesicular Bodies; ESCRT: Endosomal Sorting Complexes Required for Transport; MVs: Microvesicles; MPs: Microparticles; IncRNA: Long noncoding RNA; FEV: Forced Expiratory Volume; TF: Tissue Factor; BALF: Bronchoalveolar Lavage Fluid; EMPs: Endothelial-derived Microparticles; PH: Pulmonary Hypertension; PAH: Pulmonary Arterial Hypertension; IPAH: Idiopathic Pulmonary Arterial Hypertension; HPASMCs: Human Pulmonary Arterial Smooth Muscle Cells; MCT-PAH: Monocrotaline-induced Pulmonary Arterial Hypertension; AHR: Airway Hyper Responsiveness; ECs: Endothelial Cells; PMVECs: Pulmonary Microvascular Endothelial Cells; SMCs: Smooth Muscle Cells; NSCLC: Non-Small Cell Lung Cancer; MMPs: Matrix Metalloproteinases; MSC: Mesenchymal stem cells; EPCs: Endothelial Progenitor Cells

\section{Acknowledgements}

We acknowledge the Smith Intellectual and Development Disabilities Research Center (NIH U54 HD 090216) Core Services for the assistance in preparing figures.

\section{Authors' contributions}

NKD conceived the concept of the review paper. AM, SA performed the literature search, coordinated with the selection of data presented in the manuscript and wrote the first draft of the manuscript. All authors critically reviewed the manuscript, contributed to and approved the final version.

\section{Funding}

This work was supported by National Institutes of Health under award numbers: R01DA042715, R01HL129875 and P20 GM103638.

\section{Availability of data and materials}

All publications discussed in the manuscript are available from the corresponding author on request.

\section{Ethics approval and consent to participate}

Not applicable.

\section{Consent for publication}

Not applicable.

\section{Competing interests}

The authors declare that they have no competing interests.

\section{Author details}

${ }^{1}$ Division of Pulmonary and Critical Care Medicine, Department of Internal Medicine, University of Kansas Medical Center, Mail Stop 3007, 3901 Rainbow Blvd, Kansas City, KS 66160, USA. 'Division of Pulmonary, Critical Care, Sleep \& Occupational Medicine, Indiana University School of Medicine, Indianapolis, Indiana, USA. ${ }^{3}$ Department of Pharmacy Practice, University of Kansas School of Pharmacy, Lawrence, Kansas, USA. ${ }^{4}$ Division of Infectious Diseases, Department of Internal Medicine, University of Kansas Medical Center, Kansas City, Kansas, USA. ${ }^{5}$ Department of Molecular \& Integrative Physiology, University of Kansas Medical Center, Kansas City, Kansas, USA.
Received: 8 December 2019 Accepted: 15 June 2020

Published online: 08 July 2020

\section{References}

1. Lai FW, Lichty BD, Bowdish DM. Microvesicles: ubiquitous contributors to infection and immunity. J Leukoc Biol. 2015;97:237-45.

2. Johnstone RM. The Jeanne Manery-Fisher Memorial Lecture 1991. Maturation of reticulocytes: formation of exosomes as a mechanism for shedding membrane proteins. Biochem Cell Biol. 1992;(70):179-90.

3. Harding C, Heuser J, Stahl P. Receptor-mediated endocytosis of transferrin and recycling of the transferrin receptor in rat reticulocytes. J Cell Biol. 1983; 97:329-39.

4. Sandberg H, Andersson LO, Hoglund S. Isolation and characterization of lipid-protein particles containing platelet factor 3 released from human platelets. Biochem J. 1982;203:303-11.

5. Wolf $P$. The nature and significance of platelet products in human plasma. Br J Haematol. 1967;13:269-88.

6. Deatherage BL, Cookson BT. Membrane vesicle release in bacteria, eukaryotes, and archaea: a conserved yet underappreciated aspect of microbial life. Infect Immun. 2012:80:1948-57.

7. Bishop DG, Work E. An extracellular glycolipid produced by Escherichia coli grown under lysine-limiting conditions. Biochem J. 1965;96:567-76.

8. Pan BT, Teng K, Wu C, Adam M, Johnstone RM. Electron microscopic evidence for externalization of the transferrin receptor in vesicular form in sheep reticulocytes. J Cell Biol. 1985;101:942-8.

9. Chatterjee SN, Das J. Electron microscopic observations on the excretion of cell-wall material by Vibrio cholerae. J Gen Microbiol. 1967;49:1-11.

10. van Dongen HM, Masoumi N, Witwer KW, Pegtel DM. Extracellular Vesicles Exploit Viral Entry Routes for Cargo Delivery. Microbiol Mol Biol Rev. 2016;80: 369-86.

11. Hong BS, Cho JH, Kim H, Choi EJ, Rho S, Kim J, Kim JH, Choi DS, Kim YK, Hwang D, Gho YS. Colorectal cancer cell-derived microvesicles are enriched in cell cycle-related mRNAs that promote proliferation of endothelial cells. BMC Genomics. 2009;10:556.

12. Desrochers LM, Antonyak MA, Cerione RA. Extracellular Vesicles: Satellites of Information Transfer in Cancer and Stem Cell Biology. Dev Cell. 2016;37:301-9.

13. Vidal M. Exosomes: Revisiting their role as "garbage bags". Traffic. 2019;20: 815-28.

14. Meldolesi J. Ectosomes and exosomes-two extracellular vesicles that differ only in some details. Biochem Mol Bio J. 2016;2.

15. Owens AP 3rd, Mackman N. Microparticles in hemostasis and thrombosis. Circ Res. 2011;108:1284-97

16. Crescitelli R, Lasser C, Szabo TG, Kittel A, Eldh M, Dianzani I, Buzas El, Lotvall J. Distinct RNA profiles in subpopulations of extracellular vesicles: apoptotic bodies, microvesicles and exosomes. J Extracell Vesicles. 2013;2:20677.

17. van der Pol E, Boing AN, Gool EL, Nieuwland R. Recent developments in the nomenclature, presence, isolation, detection and clinical impact of extracellular vesicles. J Thromb Haemost. 2016;14:48-56.

18. Raposo G, Stoorvogel W. Extracellular vesicles: exosomes, microvesicles, and friends. J Cell Biol. 2013;200:373-83.

19. Czernek L, Duchler M. Functions of Cancer-Derived Extracellular Vesicles in Immunosuppression. Arch Immunol Ther Exp (Warsz). 2017;65:311-23.

20. Choi DS, Kim DK, Kim YK, Gho YS. Proteomics of extracellular vesicles: Exosomes and ectosomes. Mass Spectrom Rev. 2015;34:474-90.

21. Cocucci E, Meldolesi J. Ectosomes and exosomes: shedding the confusion between extracellular vesicles. Trends Cell Biol. 2015;25:364-72.

22. Kim YS, Kim JY, Cho R, Shin DM, Lee SW, Oh YM. Adipose stem cell-derived nanovesicles inhibit emphysema primarily via an FGF2-dependent pathway. Exp Mol Med. 2017;49:e284.

23. Shen B, Wu N, Yang JM, Gould SJ. Protein targeting to exosomes/microvesicles by plasma membrane anchors. J Biol Chem. 2011;286:14383-95.

24. Thery C, Boussac M, Veron P, Ricciardi-Castagnoli P, Raposo G, Garin J, Amigorena S. Proteomic analysis of dendritic cell-derived exosomes: a secreted subcellular compartment distinct from apoptotic vesicles. J Immunol. 2001;166:7309-18.

25. Marsh M, van Meer G. Cell biology. No ESCRTs for exosomes. Science. 2008; 319:1191-2.

26. Trajkovic K, Hsu C, Chiantia S, Rajendran L, Wenzel D, Wieland F, Schwille P, Brugger B, Simons M. Ceramide triggers budding of exosome vesicles into multivesicular endosomes. Science. 2008;319:1244-7. 
27. Perez-Hernandez D, Gutierrez-Vazquez C, Jorge I, Lopez-Martin S, Ursa A, Sanchez-Madrid F, Vazquez J, Yanez-Mo M. The intracellular interactome of tetraspanin-enriched microdomains reveals their function as sorting machineries toward exosomes. J Biol Chem. 2013:288:11649-61.

28. Chairoungdua A, Smith DL, Pochard P, Hull M, Caplan MJ. Exosome release of beta-catenin: a novel mechanism that antagonizes Wnt signaling. J Cell Biol. 2010;190:1079-91.

29. Bianco F, Perrotta C, Novellino L, Francolini M, Riganti L, Menna E, Saglietti L, Schuchman EH, Furlan R, Clementi E, et al. Acid sphingomyelinase activity triggers microparticle release from glial cells. EMBO J. 2009;28:1043-54.

30. Hurley $\mathrm{JH}$, Emr SD. The ESCRT complexes: structure and mechanism of a membrane-trafficking network. Annu Rev Biophys Biomol Struct. 2006;35:277-98.

31. Buschow SI, Nolte-'t Hoen EN, van Niel G, Pols MS, ten Broeke T, Lauwen M, Ossendorp F, Melief CJ, Raposo G, Wubbolts R, et al. MHC II in dendritic cells is targeted to lysosomes or T cell-induced exosomes via distinct multivesicular body pathways. Traffic. 2009;10:1528-42.

32. Stuffers S, Sem Wegner C, Stenmark H, Brech A. Multivesicular endosome biogenesis in the absence of ESCRTs. Traffic. 2009;10:925-37.

33. Fevrier B, Raposo G. Exosomes: endosomal-derived vesicles shipping extracellular messages. Curr Opin Cell Biol. 2004;16:415-21.

34. Akers JC, Gonda D, Kim R, Carter BS, Chen CC. Biogenesis of extracellular vesicles (EV): exosomes, microvesicles, retrovirus-like vesicles, and apoptotic bodies. J Neurooncol. 2013;113:1-11.

35. Hanson PI, Cashikar A. Multivesicular body morphogenesis. Annu Rev Cell Dev Biol. 2012;28:337-62

36. McCullough J, Fisher RD, Whitby FG, Sundquist WI, Hill CP. ALIX-CHMP4 interactions in the human ESCRT pathway. Proc Natl Acad Sci U S A. 2008; 105:7687-91.

37. Mignot G, Roux S, Thery C, Segura E, Zitvogel L. Prospects for exosomes in immunotherapy of cancer. J Cell Mol Med. 2006;10:376-88.

38. Frydrychowicz M, Kolecka-Bednarczyk A, Madejczyk M, Yasar S, Dworacki G. Exosomes - structure, biogenesis and biological role in non-small-cell lung cancer. Scand J Immunol. 2015;81:2-10.

39. Wubbolts R, Leckie RS, Veenhuizen PT, Schwarzmann G, Mobius W, Hoernschemeyer J, Slot JW, Geuze HJ, Stoorvogel W. Proteomic and biochemical analyses of human B cell-derived exosomes. Potentia implications for their function and multivesicular body formation. J Biol Chem. 2003;278:10963-72.

40. Thery C, Ostrowski M, Segura E. Membrane vesicles as conveyors of immune responses. Nat Rev Immunol. 2009;9:581-93.

41. Thery C, Regnault A, Garin J, Wolfers J, Zitvogel L, Ricciardi-Castagnoli P, Raposo G, Amigorena S. Molecular characterization of dendritic cell-derived exosomes. Selective accumulation of the heat shock protein hsc73. J Cell Biol. 1999;147:599-610

42. Hannafon BN, Ding WQ. Intercellular communication by exosome-derived microRNAs in cancer. Int J Mol Sci. 2013;14:14240-69.

43. Subra C, Grand D, Laulagnier K, Stella A, Lambeau G, Paillasse M, De Medina P, Monsarrat B, Perret B, Silvente-Poirot S, et al. Exosomes account for vesicle-mediated transcellular transport of activatable phospholipases and prostaglandins. J Lipid Res. 2010;51:2105-20.

44. Cocucci E, Racchetti G, Meldolesi J. Shedding microvesicles: artefacts no more. Trends Cell Biol. 2009;19:43-51.

45. Chaput $\mathrm{N}$, Thery C. Exosomes: immune properties and potential clinical implementations. Semin Immunopathol. 2011;33:419-40.

46. Record M, Subra C, Silvente-Poirot S, Poirot M. Exosomes as intercellular signalosomes and pharmacological effectors. Biochem Pharmacol. 2011;81: 1171-82.

47. Bard MP, Hegmans JP, Hemmes A, Luider TM, Willemsen R, Severijnen LA, van Meerbeeck JP, Burgers SA, Hoogsteden HC, Lambrecht BN. Proteomic analysis of exosomes isolated from human malignant pleural effusions. Am J Respir Cell Mol Biol. 2004;31:114-21.

48. Chaput N, Taieb J, Andre F, Zitvogel L. The potential of exosomes in immunotherapy. Expert Opin Biol Ther. 2005;5:737-47.

49. Bobrie A, Colombo M, Raposo G, Thery C. Exosome secretion: molecular mechanisms and roles in immune responses. Traffic. 2011;12:1659-68.

50. Schorey JS, Bhatnagar S. Exosome function: from tumor immunology to pathogen biology. Traffic. 2008;9:871-81.

51. Mears R, Craven RA, Hanrahan S, Totty N, Upton C, Young SL, Patel P, Selby PJ, Banks RE. Proteomic analysis of melanoma-derived exosomes by twodimensional polyacrylamide gel electrophoresis and mass spectrometry. Proteomics. 2004;4:4019-31.
52. Rana S, Malinowska K, Zoller M. Exosomal tumor microRNA modulates premetastatic organ cells. Neoplasia. 2013;15:281-95.

53. Gezer U, Ozgur E, Cetinkaya M, Isin M, Dalay N. Long non-coding RNAs with low expression levels in cells are enriched in secreted exosomes. Cell Biol Int. 2014;38:1076-9.

54. Villarroya-Beltri C, Baixauli F, Gutierrez-Vazquez C, Sanchez-Madrid F, Mittelbrunn M. Sorting it out: regulation of exosome loading. Semin Cancer Biol. 2014;28:3-13.

55. Qu X, Li Q, Yang J, Zhao H, Wang F, Zhang F, Zhang S, Zhang H, Wang R, Wang Q, et al. Double-Stranded DNA in Exosomes of Malignant Pleural Effusions as a Novel DNA Source for EGFR Mutation Detection in Lung Adenocarcinoma. Front Oncol. 2019;9:931.

56. Fernando MR, Jiang C, Krzyzanowski GD, Ryan WL. New evidence that a large proportion of human blood plasma cell-free DNA is localized in exosomes. PLoS One. 2017;12:e0183915.

57. Thakur BK, Zhang H, Becker A, Matei I, Huang Y, Costa-Silva B, Zheng Y, Hoshino A, Brazier H, Xiang J, et al. Double-stranded DNA in exosomes: a novel biomarker in cancer detection. Cell Res. 2014;24:766-9.

58. Vagner T, Spinelli C, Minciacchi VR, Balaj L, Zandian M, Conley A, Zijlstra A, Freeman MR, Demichelis F, De S, et al. Large extracellular vesicles carry most of the tumour DNA circulating in prostate cancer patient plasma. J Extracell Vesicles. 2018;7:1505403.

59. Cai J, Han Y, Ren H, Chen C, He D, Zhou L, Eisner GM, Asico LD, Jose PA, Zeng C. Extracellular vesicle-mediated transfer of donor genomic DNA to recipient cells is a novel mechanism for genetic influence between cells. J Mol Cell Biol. 2013;5:227-38.

60. Torralba D, Baixauli F, Villarroya-Beltri C, Fernandez-Delgado I, Latorre-Pellicer A, Acin-Perez R, Martin-Cofreces NB, Jaso-Tamame AL, Iborra S, Jorge I, et al. Priming of dendritic cells by DNA-containing extracellular vesicles from activated T cells through antigen-driven contacts. Nat Commun. 2018;9: 2658.

61. Rechavi O, Goldstein I, Kloog Y. Intercellular exchange of proteins: the immune cell habit of sharing. FEBS Lett. 2009;583:1792-9.

62. Mincheva-Nilsson L, Baranov V. Placenta-derived exosomes and syncytiotrophoblast microparticles and their role in human reproduction: immune modulation for pregnancy success. Am J Reprod Immunol. 2014; 72:440-57.

63. Ratajczak J, Miekus K, Kucia M, Zhang J, Reca R, Dvorak P, Ratajczak MZ. Embryonic stem cell-derived microvesicles reprogram hematopoietic progenitors: evidence for horizontal transfer of mRNA and protein delivery. Leukemia. 2006:20:847-56.

64. Gould SJ, Raposo G. As we wait: coping with an imperfect nomenclature for extracellular vesicles. J Extracell Vesicles. 2013:2:20389.

65. van der Pol E, Boing AN, Harrison P, Sturk A, Nieuwland R. Classification, functions, and clinical relevance of extracellular vesicles. Pharmacol Rev. 2012;64:676-705.

66. Hugel B, Martinez MC, Kunzelmann C, Freyssinet JM. Membrane microparticles: two sides of the coin. Physiology (Bethesda). 2005;20:22-7.

67. Scott S, Pendlebury SA, Green C. Lipid organization in erythrocyte membrane microvesicles. Biochem J. 1984;224:285-90.

68. Kastelowitz $\mathrm{N}$, Yin $\mathrm{H}$. Exosomes and microvesicles: identification and targeting by particle size and lipid chemical probes. Chembiochem. 2014;15 923-8.

69. Pizzirani C, Ferrari D, Chiozzi P, Adinolfi E, Sandona D, Savaglio E, Di Virgilio F. Stimulation of $P 2$ receptors causes release of $\mathrm{IL}-1$ beta-loaded microvesicles from human dendritic cells. Blood. 2007;109:3856-64.

70. Bianco F, Pravettoni E, Colombo A, Schenk U, Moller T, Matteoli M, Verderio C. Astrocyte-derived ATP induces vesicle shedding and IL-1 beta release from microglia. J Immunol. 2005;174:7268-77.

71. Ratajczak J, Wysoczynski M, Hayek F, Janowska-Wieczorek A, Ratajczak MZ Membrane-derived microvesicles: important and underappreciated mediators of cell-to-cell communication. Leukemia. 2006:20:1487-95.

72. Pilzer D, Gasser O, Moskovich O, Schifferli JA, Fishelson Z. Emission of membrane vesicles: roles in complement resistance, immunity and cancer. Springer Semin Immunopathol. 2005;27:375-87.

73. Chiou NT, Kageyama R, Ansel KM. Selective Export into Extracellular Vesicles and Function of tRNA Fragments during T Cell Activation. Cell Rep. 2018;25: 3356-70 e3354.

74. Hristov M, Erl W, Linder S, Weber PC. Apoptotic bodies from endothelial cells enhance the number and initiate the differentiation of human endothelial progenitor cells in vitro. Blood. 2004;104:2761-6. 
75. Turiak L, Misjak P, Szabo TG, Aradi B, Paloczi K, Ozohanics O, Drahos L, Kittel A, Falus A, Buzas El, Vekey K. Proteomic characterization of thymocytederived microvesicles and apoptotic bodies in BALB/c mice. J Proteomics. 2011;74:2025-33.

76. Kerr JF, Wyllie AH, Currie AR. Apoptosis: a basic biological phenomenon with wide-ranging implications in tissue kinetics. Br J Cancer. 1972;26:239-57.

77. Bilyy RO, Shkandina T, Tomin A, Munoz LE, Franz S, Antonyuk V, Kit YY, Zirngibl M, Furnrohr BG, Janko C, et al. Macrophages discriminate glycosylation patterns of apoptotic cell-derived microparticles. J Biol Chem. 2012;287:496-503.

78. Oberemko A, Popandopulo A. Extracellular vesicles: classification, functions and clinical relevance. Biotechnologia Acta. 2014;7:102-33108.

79. Schiller M, Bekeredjian-Ding I, Heyder P, Blank N, Ho AD, Lorenz HM. Autoantigens are translocated into small apoptotic bodies during early stages of apoptosis. Cell Death Differ. 2008;15:183-91.

80. Cocca BA, Cline AM, Radic MZ. Blebs and apoptotic bodies are B cell autoantigens. J Immunol. 2002;169:159-66.

81. Hogg JC, Chu F, Utokaparch S, Woods R, Elliott WM, Buzatu L, Cherniack RM, Rogers RM, Sciurba FC, Coxson HO, Pare PD. The nature of small-airway obstruction in chronic obstructive pulmonary disease. N Engl J Med. 2004; 350:2645-53.

82. Brusselle GG, Joos GF, Bracke KR. New insights into the immunology of chronic obstructive pulmonary disease. Lancet. 2011;378:1015-26.

83. Kadota T, Fujita Y, Yoshioka Y, Araya J, Kuwano K, Ochiya T. Emerging role of extracellular vesicles as a senescence-associated secretory phenotype: Insights into the pathophysiology of lung diseases. Mol Aspects Med. 2018; 60:92-103.

84. Takahashi T, Kubo H. The role of microparticles in chronic obstructive pulmonary disease. Int J Chron Obstruct Pulmon Dis. 2014;9:303-14.

85. Tokes-Fuzesi M, Ruzsics I, Rideg O, Kustan P, Kovacs GL, Molnar T. Role of microparticles derived from monocytes, endothelial cells and platelets in the exacerbation of COPD. Int J Chron Obstruct Pulmon Dis. 2018;13:3749-57.

86. Thomashow MA, Shimbo D, Parikh MA, Hoffman EA, Vogel-Claussen J, Hueper K, Fu J, Liu CY, Bluemke DA, Ventetuolo CE, et al. Endothelial microparticles in mild chronic obstructive pulmonary disease and emphysema. The Multi-Ethnic Study of Atherosclerosis Chronic Obstructive Pulmonary Disease study. Am J Respir Crit Care Med. 2013;188:60-8.

87. Strulovici-Barel Y, Staudt MR, Krause A, Gordon C, Tilley AE, Harvey BG, Kaner RJ, Hollmann C, Mezey JG, Bitter $H$, et al. Persistence of circulating endothelial microparticles in COPD despite smoking cessation. Thorax. 2016; 71:1137-44.

88. Takahashi T, Kobayashi S, Fujino N, Suzuki T, Ota C, Tando Y, Yamada M, Yanai M, Yamaya M, Kurosawa S, et al. Annual FEV1 changes and numbers of circulating endothelial microparticles in patients with COPD: a prospective study. BMJ Open. 2014;4:e004571.

89. Takahashi T, Kobayashi S, Fujino N, Suzuki T, Ota C, He M, Yamada M, Suzuki S, Yanai M, Kurosawa S, et al. Increased circulating endothelial microparticles in COPD patients: a potential biomarker for COPD exacerbation susceptibility. Thorax. 2012:67:1067-74.

90. Serban KA, Rezania S, Petrusca DN, Poirier C, Cao D, Justice MJ, Patel M, Tsvetkova I, Kamocki K, Mikosz A, et al. Structural and functional characterization of endothelial microparticles released by cigarette smoke. Sci Rep. 2016;6:31596.

91. Visovatti SH, Hyman MC, Bouis D, Neubig R, McLaughlin W, Pinsky DJ. Increased CD39 nucleotidase activity on microparticles from patients with idiopathic pulmonary arterial hypertension. PLoS One. 2012;7:e40829.

92. Ferrer E, Dunmore BJ, Hassan D, Ormiston ML, Moore S, Deighton J, Long L, Yang XD, Stewart DJ, Morrell NW. A Potential Role for Exosomal Translationally Controlled Tumor Protein Export in Vascular Remodeling in Pulmonary Arterial Hypertension. Am J Respir Cell Mol Biol. 2018;59:467-78.

93. Zhao L, Luo H, Li X, Li T, He J, Qi Q, Liu Y, Yu Z. Exosomes Derived from Human Pulmonary Artery Endothelial Cells Shift the Balance between Proliferation and Apoptosis of Smooth Muscle Cells. Cardiology. 2017;137:43-53.

94. Nadaud S, Poirier O, Girerd B, Blanc C, Montani D, Eyries M, Imbert-Bismut F, Pacheco A, Vigne J, Tregouet DA, et al. Small platelet microparticle levels are increased in pulmonary arterial hypertension. Eur J Clin Invest. 2013;43:64-71.

95. Amabile N, Heiss C, Real WM, Minasi P, McGlothlin D, Rame EJ, Grossman W, De Marco T, Yeghiazarians Y. Circulating endothelial microparticle levels predict hemodynamic severity of pulmonary hypertension. Am J Respir Crit Care Med. 2008;177:1268-75.
96. Amabile N, Heiss C, Chang V, Angeli FS, Damon L, Rame EJ, McGlothlin D, Grossman W, De Marco T, Yeghiazarians Y. Increased CD62e(+) endothelial microparticle levels predict poor outcome in pulmonary hypertension patients. J Heart Lung Transplant. 2009;28:1081-6.

97. Rose JA, Wanner N, Cheong HI, Queisser K, Barrett P, Park M, Hite C, Naga Prasad SV, Erzurum S, Asosingh K. Flow Cytometric Quantification of Peripheral Blood Cell beta-Adrenergic Receptor Density and Urinary Endothelial Cell-Derived Microparticles in Pulmonary Arterial Hypertension. PLoS One. 2016;11:e0156940.

98. Bakouboula B, Morel O, Faure A, Zobairi F, Jesel L, Trinh A, Zupan M, Canuet M, Grunebaum L, Brunette A, et al. Procoagulant membrane microparticles correlate with the severity of pulmonary arterial hypertension. Am J Respir Crit Care Med. 2008;177:536-43.

99. Diehl P, Aleker M, Helbing T, Sossong V, Germann M, Sorichter S, Bode C, Moser M. Increased platelet, leukocyte and endothelial microparticles predict enhanced coagulation and vascular inflammation in pulmonary hypertension. J Thromb Thrombolysis. 2011;31:173-9.

100. Mazzeo C, Canas JA, Zafra MP, Rojas Marco A, Fernandez-Nieto M, Sanz V, Mittelbrunn M, Izquierdo M, Baixaulli F, Sastre J, Del Pozo V. Exosome secretion by eosinophils: A possible role in asthma pathogenesis. J Allergy Clin Immunol. 2015:135:1603-13.

101. Canas JA, Sastre B, Rodrigo-Munoz JM, Fernandez-Nieto M, Barranco P, Quirce S, Sastre J, Del Pozo V. Eosinophil-derived exosomes contribute to asthma remodelling by activating structural lung cells. Clin Exp Allergy. 2018:48:1173-85.

102. Torregrosa Paredes P, Esser J, Admyre C, Nord M, Rahman QK, Lukic A, Radmark O, Gronneberg R, Grunewald J, Eklund A, et al. Bronchoalveolar lavage fluid exosomes contribute to cytokine and leukotriene production in allergic asthma. Allergy. 2012;67:911-9.

103. Hough KP, Trevor JL, Strenkowski JG, Wang Y, Chacko BK, Tousif S, Chanda D, Steele C, Antony VB, Dokland T, et al. Exosomal transfer of mitochondria from aimay myeloid-derived regulatory cells to T cells. Redox Biol. 2018;18:54-64.

104. Hough KP, Wilson LS, Trevor JL, Strenkowski JG, Maina N, Kim Yl, Spell ML, Wang Y, Chanda D, Dager JR, et al. Unique Lipid Signatures of Extracellular Vesicles from the Airways of Asthmatics. Sci Rep. 2018;8:10340.

105. Rahman MA, Barger JF, Lovat F, Gao M, Otterson GA, Nana-Sinkam P. Lung cancer exosomes as drivers of epithelial mesenchymal transition. Oncotarget. 2016;7:54852-66.

106. Zhang R, Xia Y, Wang Z, Zheng J, Chen Y, Li X, Wang Y, Ming H. Serum long non coding RNA MALAT-1 protected by exosomes is up-regulated and promotes cell proliferation and migration in non-small cell lung cancer. Biochem Biophys Res Commun. 2017:490:406-14.

107. Guervilly C, Lacroix R, Forel JM, Roch A, Camoin-Jau L, Papazian L, DignatGeorge F. High levels of circulating leukocyte microparticles are associated with better outcome in acute respiratory distress syndrome. Crit Care. 2011; 15:R31.

108. Mitra S, Exline M, Habyarimana F, Gavrilin MA, Baker PJ, Masters SL, Wewers MD, Sarkar A. Microparticulate Caspase 1 Regulates Gasdermin D and Pulmonary Vascular Endothelial Cell Injury. Am J Respir Cell Mol Biol. 2018; 59:56-64.

109. Kerr NA, de Rivero Vaccari JP, Umland O, Bullock MR, Conner GE, Dietrich WD, Keane RW. Human Lung Cell Pyroptosis Following Traumatic Brain Injury. Cells. 2019;8:69.

110. Bastarache JA, Fremont RD, Kropski JA, Bossert FR, Ware LB. Procoagulant alveolar microparticles in the lungs of patients with acute respiratory distress syndrome. Am J Physiol Lung Cell Mol Physiol. 2009;297:L1035-41.

111. Lashin HMS, Nadkarni S, Oggero S, Jones HR, Knight JC, Hinds CJ, Perretti M. Microvesicle Subsets in Sepsis Due to Community Acquired Pneumonia Compared to Faecal Peritonitis. Shock. 2018;49:393-401.

112. Dalli J, Norling LV, Montero-Melendez T, Federici Canova D, Lashin H, Pavlov AM, Sukhorukov GB, Hinds CJ, Perretti M. Microparticle alpha-2macroglobulin enhances pro-resolving responses and promotes survival in sepsis. EMBO Mol Med. 2014;6:27-42.

113. Li CJ, Liu Y, Chen Y, Yu D, Williams KJ, Liu ML. Novel proteolytic microvesicles released from human macrophages after exposure to tobacco smoke. Am J Pathol. 2013;182:1552-62.

114. Cordazzo C, Petrini S, Neri T, Lombardi S, Carmazzi Y, Pedrinelli R, Paggiaro P. Celi A. Rapid shedding of proinflammatory microparticles by human mononuclear cells exposed to cigarette smoke is dependent on Ca2+ mobilization. Inflamm Res. 2014;63:539-47. 
115. Li M, Yu D, Williams KJ, Liu ML. Tobacco smoke induces the generation of procoagulant microvesicles from human monocytes/macrophages. Arterioscler Thromb Vasc Biol. 2010;30:1818-24.

116. Kubo H. Extracellular Vesicles in Lung Disease. Chest. 2018;153:210-6.

117. Genschmer KR, Russell DW, Lal C, Szul T, Bratcher PE, Noerager BD, Abdul Roda M, Xu X, Rezonzew G, Viera L, et al. Activated PMN Exosomes: Pathogenic Entities Causing Matrix Destruction and Disease in the Lung. Cell. 2019;176:113-26 e115.

118. Chelvanambi S, Bogatcheva NV, Bednorz M, Agarwal S, Maier B, Alves NJ, Li W, Syed F, Saber MM, Dahl N, et al. HIV-Nef Protein Persists in the Lungs of Aviremic Patients with HIV and Induces Endothelial Cell Death. Am J Respir Cell Mol Biol. 2019;60:357-66.

119. Liu H, Ding L, Zhang Y, Ni S. Circulating endothelial microparticles involved in lung function decline in a rat exposed in cigarette smoke maybe from apoptotic pulmonary capillary endothelial cells. J Thorac Dis. 2014;6:649-55.

120. Feller D, Kun J, Ruzsics I, Rapp J, Sarosi V, Kvell K, Helyes Z, Pongracz JE. Cigarette Smoke-Induced Pulmonary Inflammation Becomes Systemic by Circulating Extracellular Vesicles Containing Wnt5a and Inflammatory Cytokines. Front Immunol. 2018;9:1724.

121. Moon HG, Kim SH, Gao J, Quan T, Qin Z, Osorio JC, Rosas IO, Wu M, Tesfaigzi $Y$, Jin $Y$. CCN1 secretion and cleavage regulate the lung epithelial cell functions after cigarette smoke. Am J Physiol Lung Cell Mol Physiol. 2014;307:L326-37.

122. Fujita Y, Araya J, Ito S, Kobayashi K, Kosaka N, Yoshioka Y, Kadota T, Hara H, Kuwano K, Ochiya T. Suppression of autophagy by extracellular vesicles promotes myofibroblast differentiation in COPD pathogenesis. J Extracell Vesicles. 2015;4:28388.

123. Hoeper MM, Ghofrani HA, Grunig E, Klose H, Olschewski H, Rosenkranz S. Pulmonary Hypertension. Dtsch Arztebl Int. 2017;114:73-84

124. Vonk Noordegraaf A, Groeneveldt JA, Bogaard HJ. Pulmonary hypertension. Eur Respir Rev. 2016;25:4-11.

125. Manakeng K, Prasertphol P, Phongpao K, Chuncharunee S, Tanyong D, Worawichawong S, Svasti S, Chaichompoo P. Elevated levels of platelet- and red cell-derived extracellular vesicles in transfusion-dependent betathalassemia/HbE patients with pulmonary arterial hypertension. Ann Hematol. 2019:98:281-8.

126. Aliotta JM, Pereira M, Wen S, Dooner MS, Del Tatto M, Papa E, Goldberg LR, Baird GL, Ventetuolo CE, Quesenberry PJ, Klinger JR. Exosomes induce and reverse monocrotaline-induced pulmonary hypertension in mice. Cardiovasc Res. 2016;110:319-30.

127. Aliotta JM, Pereira M, Amaral A, Sorokina A, Igbinoba Z, Hasslinger A, El-Bizri R, Rounds SI, Quesenberry PJ, Klinger JR. Induction of pulmonary hypertensive changes by extracellular vesicles from monocrotaline-treated mice. Cardiovasc Res. 2013;100:354-62.

128. Aliotta J, Pereira M, Quesenberry P, Klinger J. Increased Mir107 In Pulmonary Vascular Endothelial Cells Cultured With Extracellular Vesicles Known To Induce Pulmonary Hypertension In Mice. In: America Journal of Respiratory and critical care medicine. Amer thoracic soc25 broadway, 18 FL, New York, NY 1004 USA; 2015.

129. Aliotta JM, Pereira M, Wen S, Dooner MS, Del Tatto M, Papa E, Cheng Y, Goldberg L, Ventetuolo CE, Liang O, et al. Bone Marrow Endothelial Progenitor Cells Are the Cellular Mediators of Pulmonary Hypertension in the Murine Monocrotaline Injury Model. Stem Cells Transl Med. 2017;6:1595-606.

130. Tual-Chalot S, Guibert C, Muller B, Savineau JP, Andriantsitohaina R, Martinez MC. Circulating microparticles from pulmonary hypertensive rats induce endothelial dysfunction. Am J Respir Crit Care Med. 2010;182:261-8.

131. Blair LA, Haven AK, Bauer NN. Circulating microparticles in severe pulmonary arterial hypertension increase intercellular adhesion molecule-1 expression selectively in pulmonary artery endothelium. Respir Res. 2016;17:133.

132. Deng L, Blanco FJ, Stevens H, Lu R, Caudrillier A, McBride M, McClure JD, Grant J, Thomas M, Frid M, et al. MicroRNA-143 Activation Regulates Smooth Muscle and Endothelial Cell Crosstalk in Pulmonary Arterial Hypertension. Circ Res. 2015;117:870-83.

133. Sharma H, Chinnappan M, Agarwal S, Dalvi P, Gunewardena S, O'BrienLadner A, Dhillon NK. Macrophage-derived extracellular vesicles mediate smooth muscle hyperplasia: role of altered miRNA cargo in response to HIV infection and substance abuse. FASEB J. 2018:32:5174-85.

134. Yuan K, Shamskhou EA, Orcholski ME, Nathan A, Reddy S, Honda H, Mani V, Zeng Y, Ozen MO, Wang L, et al. Loss of Endothelium-Derived Wnt5a Is Associated With Reduced Pericyte Recruitment and Small Vessel Loss in Pulmonary Arterial Hypertension. Circulation. 2019;139:1710-24.
135. Yuan K, Shamskhou EA, Orcholski ME, Nathan A, Reddy S, Honda H, Mani $V$, Zeng $Y$, Ozen $M O$, Wang $L$, et al. Loss of Endothelial Derived WNT5A is Associated with Reduced Pericyte Recruitment and Small Vessel Loss in Pulmonary Arterial Hypertension. Circulation. 2019;139: 1710-1724.

136. Rhodes CJ, Wharton J, Boon RA, Roexe T, Tsang H, Wojciak-Stothard B, Chakrabarti A, Howard LS, Gibbs JS, Lawrie A, et al. Reduced microRNA-150 is associated with poor survival in pulmonary arterial hypertension. Am J Respir Crit Care Med. 2013;187:294-302

137. Chapman DG, Irvin CG. Mechanisms of airway hyper-responsiveness in asthma: the past, present and yet to come. Clin Exp Allergy. 2015;45: 706-19.

138. Niimi A, Matsumoto $H$, Takemura M, Ueda T, Chin K, Mishima M. Relationship of airway wall thickness to airway sensitivity and airway reactivity in asthma. Am J Respir Crit Care Med. 2003;168:983-8.

139. Boulet L, Belanger M, Carrier G. Airway responsiveness and bronchial-wall thickness in asthma with or without fixed airflow obstruction. Am J Respir Crit Care Med. 1995;152:865-71.

140. James AL, Elliot JG, Jones RL, Carroll ML, Mauad T, Bai TR, Abramson MJ, McKay KO, Green FH. Airway smooth muscle hypertrophy and hyperplasia in asthma. Am J Respir Crit Care Med. 2012;185:1058-64.

141. Ribatti D, Puxeddu I, Crivellato E, Nico B, Vacca A, Levi-Schaffer F. Angiogenesis in asthma. Clin Exp Allergy. 2009;39:1815-21.

142. Wilson JW, Li X. The measurement of reticular basement membrane and submucosal collagen in the asthmatic airway. Clin Exp Allergy. 1997;27:363-71.

143. Locksley RM. Asthma and allergic inflammation. Cell. 2010;140:777-83.

144. Barnes PJ. Intrinsic asthma: not so different from allergic asthma but driven by superantigens? Clin Exp Allergy. 2009;39:1145-51.

145. Persson CG. Antiinflammatory therapy with glucocorticoids in intrinsic asthma. Agents Actions Suppl. 1989:28:279-91.

146. Peters SP. Asthma phenotypes: nonallergic (intrinsic) asthma. J Allergy Clin Immunol Pract. 2014;2:650-2.

147. Pelaia G, Vatrella A, Busceti MT, Gallelli L, Calabrese C, Terracciano R, Maselli R. Cellular mechanisms underlying eosinophilic and neutrophilic airway inflammation in asthma. Mediators Inflamm. 2015;2015:879783.

148. Wahlund CJE, Eklund A, Grunewald J, Gabrielsson S. Pulmonary Extracellular Vesicles as Mediators of Local and Systemic Inflammation. Front Cell Dev Biol. 2017:5:39.

149. Lambrecht BN, Hammad $H$. The immunology of asthma. Nat Immunol. 2015;16:45-56.

150. Perry MM, Baker JE, Gibeon DS, Adcock IM, Chung KF. Airway smooth muscle hyperproliferation is regulated by microRNA-221 in severe asthma. Am J Respir Cell Mol Biol. 2014;50:7-17.

151. Korn T, Bettelli E, Oukka M, Kuchroo VK. IL-17 and Th17 Cells. Annu Rev Immunol. 2009:27:485-517.

152. Yata K, Yaccoby S. The SCID-rab model: a novel in vivo system for primary human myeloma demonstrating growth of CD138-expressing malignant cells. Leukemia. 2004;18:1891-7.

153. Cosmi L, Liotta F, Maggi E, Romagnani S, Annunziato F. Th17 cells: new players in asthma pathogenesis. Allergy. 2011;66:989-98.

154. Newcomb DC, Peebles RS Jr. Th17-mediated inflammation in asthma. Curr Opin Immunol. 2013;25:755-60.

155. Al-Ramli W, Prefontaine D, Chouiali F, Martin JG, Olivenstein R, Lemiere C, Hamid Q. T(H)17-associated cytokines (IL-17A and IL-17F) in severe asthma. J Allergy Clin Immunol. 2009;123:1185-7.

156. Wang YH, Voo KS, Liu B, Chen CY, Uygungil B, Spoede W, Bernstein JA, Huston DP, Liu YJ. A novel subset of CD4(+) T(H)2 memory/effector cells that produce inflammatory $\mathrm{IL}-17$ cytokine and promote the exacerbation of chronic allergic asthma. J Exp Med. 2010;207:2479-91.

157. Ouyang W, Kolls JK, Zheng Y. The biological functions of T helper 17 cell effector cytokines in inflammation. Immunity. 2008;28:454-67.

158. Alcorn JF, Crowe CR, Kolls JK. TH17 cells in asthma and COPD. Annu Rev Physiol. 2010;72:495-516

159. Ano S, Morishima $Y$, Ishii $Y$, Yoh K, Yageta Y, Ohtsuka S, Matsuyama M, Kawaguchi M, Takahashi S, Hizawa N. Transcription factors GATA-3 and RORgammat are important for determining the phenotype of allergic airway inflammation in a murine model of asthma. J Immunol. 2013;190:1056.

160. McKinley L, Alcorn JF, Peterson A, Dupont RB, Kapadia S, Logar A, Henry A, Irvin CG, Piganelli JD, Ray A, Kolls JK. TH17 cells mediate steroid-resistant airway inflammation and airway hyperresponsiveness in mice. J Immunol. 2008;181:4089-97. 
161. Mortaz E, Alipoor SD, Varahram M, Jamaati H, Garssen J, Mumby SE, Adcock IM. Exosomes in Severe Asthma: Update in Their Roles and Potential in Therapy. Biomed Res Int. 2018;2018:2862187.

162. Sastre B, Canas JA, Rodrigo-Munoz JM, Del Pozo V. Novel Modulators of Asthma and Allergy: Exosomes and MicroRNAs. Front Immunol. 2017;8:826.

163. Fujita Y, Yoshioka Y, Ito S, Araya J, Kuwano K, Ochiya T. Intercellular communication by extracellular vesicles and their microRNAs in asthma. Clin Ther. 2014;36:873-81.

164. Kulshreshtha A, Ahmad T, Agrawal A, Ghosh B. Proinflammatory role of epithelial cell-derived exosomes in allergic airway inflammation. J Allergy Clin Immunol. 2013;131:1194-203 1203 e1191-1114.

165. Canas JA, Sastre B, Mazzeo C, Fernandez-Nieto M, Rodrigo-Munoz JM, Gonzalez-Guerra A, Izquierdo M, Barranco P, Quirce S, Sastre J, Del Pozo V. Exosomes from eosinophils autoregulate and promote eosinophil functions. J Leukoc Biol. 2017:101:1191-9.

166. Haj-Salem I, Plante S, Gounni AS, Rouabhia M, Chakir J. Fibroblast-derived exosomes promote epithelial cell proliferation through TGF-beta2 signalling pathway in severe asthma. Allergy. 2018;73:178-86.

167. Admyre C, Bohle B, Johansson SM, Focke-Tejkl M, Valenta R, Scheynius A, Gabrielsson S. B cell-derived exosomes can present allergen peptides and activate allergen-specific T cells to proliferate and produce $\mathrm{TH}$ 2-like cytokines. J Allergy Clin Immunol. 2007;120:1418-24.

168. Wahlgren J, Karlson Tde L, Glader P, Telemo E, Valadi H. Activated human T cells secrete exosomes that participate in IL-2 mediated immune response signaling. PLoS One. 2012;7:e49723.

169. Skokos D, Botros HG, Demeure C, Morin J, Peronet R, Birkenmeier G, Boudaly S, Mecheri S. Mast cell-derived exosomes induce phenotypic and functional maturation of dendritic cells and elicit specific immune responses in vivo. J Immunol. 2003;170:3037-45.

170. Tkaczyk C, Villa I, Peronet R, David B, Chouaib S, Mecheri S. In vitro and in vivo immunostimulatory potential of bone marrow-derived mast cells on B- and T-lymphocyte activation. J Allergy Clin Immunol. 2000;105:134-42.

171. Xia YC, Harris T, Stewart AG, Mackay GA. Secreted factors from human mast cells trigger inflammatory cytokine production by human airway smooth muscle cells. Int Arch Allergy Immunol. 2013;160:75-85.

172. Xie G, Yang H, Peng X, Lin L, Wang J, Lin K, Cui Z, Li J, Xiao H, Liang Y, Li L. Mast cell exosomes can suppress allergic reactions by binding to $\lg \mathrm{E}$. J Allergy Clin Immunol. 2018;141:788-91.

173. Skokos D, Le Panse S, Villa I, Rousselle JC, Peronet R, David B, Namane A, Mecheri S. Mast cell-dependent B and T Iymphocyte activation is mediated by the secretion of immunologically active exosomes. J Immunol. 2001;166: 868-76.

174. Zitvogel L, Regnault A, Lozier A, Wolfers J, Flament C, Tenza D, RicciardiCastagnoli P, Raposo G, Amigorena S. Eradication of established murine tumors using a novel cell-free vaccine: dendritic cell-derived exosomes. Nat Med. 1998:4:594-600.

175. Kim MR, Hong SW, Choi EB, Lee WH, Kim YS, Jeon SG, Jang MH, Gho YS, Kim YK. Staphylococcus aureus-derived extracellular vesicles induce neutrophilic pulmonary inflammation via both Th1 and Th17 cell responses. Allergy. 2012;67:1271-81

176. Clayton A, Turkes A, Navabi H, Mason MD, Tabi Z. Induction of heat shock proteins in B-cell exosomes. J Cell Sci. 2005;118:3631-8.

177. Lindell DM, Berlin AA, Schaller MA, Lukacs NW. B cell antigen presentation promotes Th2 responses and immunopathology during chronic allergic lung disease. PLoS One. 2008;3:e3129.

178. Vargas A, Roux-Dalvai F, Droit A, Lavoie JP. Neutrophil-Derived Exosomes: A New Mechanism Contributing to Airway Smooth Muscle Remodeling. Am J Respir Cell Mol Biol. 2016;55:450-61.

179. Varricchi G, Bagnasco D, Borriello F, Heffler E, Canonica GW. Interleukin-5 pathway inhibition in the treatment of eosinophilic respiratory disorders: evidence and unmet needs. Curr Opin Allergy Clin Immunol. 2016;16:186-200.

180. Hogan SP, Rosenberg HF, Moqbel R, Phipps S, Foster PS, Lacy P, Kay AB, Rothenberg ME. Eosinophils: biological properties and role in health and disease. Clin Exp Allergy. 2008;38:709-50.

181. Gupta R, Radicioni G, Abdelwahab S, Dang H, Carpenter J, Chua M, Mieczkowski PA, Sheridan JT, Randell SH, Kesimer M. Intercellular Communication between Airway Epithelial Cells Is Mediated by ExosomeLike Vesicles. Am J Respir Cell Mol Biol. 2019;60:209-20.

182. Admyre C, Grunewald J, Thyberg J, Gripenback S, Tornling G, Eklund A, Scheynius A, Gabrielsson S. Exosomes with major histocompatibility complex class II and co-stimulatory molecules are present in human BAL fluid. Eur Respir J. 2003;22:578-83.

183. Park JA, Sharif AS, Tschumperlin DJ, Lau L, Limbrey R, Howarth P, Drazen JM. Tissue factor-bearing exosome secretion from human mechanically stimulated bronchial epithelial cells in vitro and in vivo. J Allergy Clin Immunol. 2012;130:1375-83.

184. Kerem E, Konstan MW, De Boeck K, Accurso FJ, Sermet-Gaudelus I, Wilschanski M, Elborn JS, Melotti P, Bronsveld I, Fajac I, et al. Ataluren for the treatment of nonsense-mutation cystic fibrosis: a randomised, double-blind, placebo-controlled phase 3 trial. Lancet Respir Med. 2014;2:539-47.

185. Levanen B, Bhakta NR, Torregrosa Paredes P, Barbeau R, Hiltbrunner S, Pollack JL, Skold CM, Svartengren M, Grunewald J, Gabrielsson S, et al. Altered microRNA profiles in bronchoalveolar lavage fluid exosomes in asthmatic patients. J Allergy Clin Immunol. 2013;131:894-903.

186. Kumar M, Ahmad T, Sharma A, Mabalirajan U, Kulshreshtha A, Agrawal A, Ghosh B. Let-7 microRNA-mediated regulation of IL-13 and allergic airway inflammation. J Allergy Clin Immunol. 2011;128:1077-85 e1071-1010.

187. Lu TX, Munitz A, Rothenberg ME. MicroRNA-21 is up-regulated in allergic airway inflammation and regulates IL-12p35 expression. J Immunol. 2009; 182:4994-5002.

188. Lee HY, Lee HY, Choi JY, Hur J, Kim IK, Kim YK, Kang JY, Lee SY. Inhibition of MicroRNA-21 by an antagomir ameliorates allergic inflammation in a mouse model of asthma. Exp Lung Res. 2017;43:109-19.

189. Elbehidy RM, Youssef DM, El-Shal AS, Shalaby SM, Sherbiny HS, Sherief LM, Akeel NE. MicroRNA-21 as a novel biomarker in diagnosis and response to therapy in asthmatic children. Mol Immunol. 2016;71:107-14.

190. Sawant DV, Yao W, Wright Z, Sawyers C, Tepper RS, Gupta SK, Kaplan MH, Dent AL. Serum MicroRNA-21 as a Biomarker for Allergic Inflammatory Disease in Children. Microrna. 2015;4:36-40.

191. Jude JA, Dileepan M, Subramanian S, Solway J, Panettieri RA Jr, Walseth TF Kannan MS: miR-140-3p regulation of TNF-alpha-induced CD38 expression in human airway smooth muscle cells. Am J Physiol Lung Cell Mol Physiol. 2012;303:L460-8.

192. Dileepan M, Sarver AE, Rao SP, Panettieri RA Jr, Subramanian S, Kannan MS. MicroRNA Mediated Chemokine Responses in Human Airway Smooth Muscle Cells. PLoS One. 2016;11:e0150842.

193. Specjalski K, Jassem E. MicroRNAs: Potential Biomarkers and Targets of Therapy in Allergic Diseases? Arch Immunol Ther Exp (Warsz). 2019;67: 213-23.

194. Suzuki M, Konno S, Makita H, Shimizu K, Kimura H, Kimura H, Nishimura M Altered circulating exosomal RNA profiles detected by next-generation sequencing in patients with severe asthma. Eur Respiratory Soc. 2016;48: PA3410.

195. Dela Cruz CS, Tanoue LT, Matthay RA. Lung cancer: epidemiology, etiology, and prevention. Clin Chest Med. 2011:32:605-44.

196. Wynder EL, Hoffmann D. Smoking and lung cancer: scientific challenges and opportunities. Cancer Res. 1994:54:5284-95.

197. Spitz MR, Etzel CJ, Dong Q, Amos Cl, Wei Q, Wu X, Hong WK. An expanded risk prediction model for lung cancer. Cancer Prev Res (Phila). 2008;1:250-4.

198. Wakelee HA, Chang ET, Gomez SL, Keegan TH, Feskanich D, Clarke CA Holmberg L, Yong LC, Kolonel LN, Gould MK, West DW. Lung cancer incidence in never smokers. J Clin Oncol. 2007:25:472-8.

199. Ruano-Ravina A, Figueiras A, Barros-Dios JM. Diet and lung cancer: a new approach. Eur J Cancer Prev. 2000:9:395-400.

200. Lavole A, Wislez M, Antoine M, Mayaud C, Milleron B, Cadranel J. Lung cancer, a new challenge in the HIV-infected population. Lung Cancer. 2006; $51: 1-11$.

201. Rezazadeh A, Laber DA, Ghim SJ, Jenson AB, Kloecker G. The role of human papilloma virus in lung cancer: a review of the evidence. Am J Med Sci. 2009:338:64-7.

202. Liu S, Zhan Y, Luo J, Feng J, Lu J, Zheng H, Wen Q, Fan S. Roles of exosomes in the carcinogenesis and clinical therapy of non-small cell lung cancer. Biomed Pharmacother. 2019:111:338-46.

203. Zhou L, Lv T, Zhang Q, Zhu Q, Zhan P, Zhu S, Zhang J, Song Y. The biology, function and clinical implications of exosomes in lung cancer. Cancer Lett. 2017:407:84-92

204. Li X, Wang S, Zhu R, Li H, Han Q, Zhao RC. Lung tumor exosomes induce a pro-inflammatory phenotype in mesenchymal stem cells via NFkappaB-TLR signaling pathway. J Hematol Oncol. 2016;9:42. 
205. Wang Y, Yi J, Chen X, Zhang Y, Xu M, Yang Z. The regulation of cancer cell migration by lung cancer cell-derived exosomes through TGF-beta and IL10. Oncol Lett. 2016;11:1527-30.

206. Zheng H, Zhan Y, Liu S, Lu J, Luo J, Feng J, Fan S. The roles of tumorderived exosomes in non-small cell lung cancer and their clinical implications. J Exp Clin Cancer Res. 2018;37:226.

207. Zhao H, Yang L, Baddour J, Achreja A, Bernard V, Moss T, Marini JC, Tudawe T, Seviour EG, San Lucas FA, et al. Tumor microenvironment derived exosomes pleiotropically modulate cancer cell metabolism. Elife. 2016;5: e10250.

208. Bobrie A, Krumeich S, Reyal F, Recchi C, Moita LF, Seabra MC, Ostrowski M, Thery C. Rab27a supports exosome-dependent and -independent mechanisms that modify the tumor microenvironment and can promote tumor progression. Cancer Res. 2012;72:4920-30.

209. Lukic A, Wahlund CJE, Gomez C, Brodin D, Samuelsson B, Wheelock CE, Gabrielsson S, Radmark O. Exosomes and cells from lung cancer pleural exudates transform LTC4 to LTD4, promoting cell migration and survival via CysLT1. Cancer Lett. 2019;444:1-8.

210. Liang H, Yan X, Pan Y, Wang Y, Wang N, Li L, Liu Y, Chen X, Zhang CY, Gu $H$, Zen K. MicroRNA-223 delivered by platelet-derived microvesicles promotes lung cancer cell invasion via targeting tumor suppressor EPB41L3. Mol Cancer. 2015;14:58.

211. Vanni I, Alama A, Grossi F, Dal Bello MG, Coco S. Exosomes: a new horizon in lung cancer. Drug Discov Today. 2017;22:927-36.

212. Gutkin A, Uziel O, Beery E, Nordenberg J, Pinchasi M, Goldvaser H, Henick S, Goldberg M, Lahav M. Tumor cells derived exosomes contain hTERT mRNA and transform nonmalignant fibroblasts into telomerase positive cells. Oncotarget. 2016;7:59173-88.

213. Chen L, Feng Z, Yue H, Bazdar D, Mbonye U, Zender C, Harding CV, Bruggeman L, Karn J, Sieg SF, et al. Exosomes derived from HIV-1-infected cells promote growth and progression of cancer via HIV TAR RNA. Nat Commun. 2018;9:4585.

214. Liu Y, Luo F, Wang B, Li H, Xu Y, Liu X, Shi L, Lu X, Xu W, Lu L, et al. STAT3regulated exosomal miR-21 promotes angiogenesis and is involved in neoplastic processes of transformed human bronchial epithelial cells. Cancer Lett. 2016;370:125-35.

215. Ren W, Hou J, Yang C, Wang H, Wu S, Wu Y, Zhao X, Lu C. Extracellular vesicles secreted by hypoxia pre-challenged mesenchymal stem cells promote non-small cell lung cancer cell growth and mobility as well as macrophage M2 polarization via miR-21-5p delivery. J Exp Clin Cancer Res. 2019;38:62.

216. Hsu YL, Hung JY, Chang WA, Lin YS, Pan YC, Tsai PH, Wu CY, Kuo PL. Hypoxic lung cancer-secreted exosomal miR-23a increased angiogenesis and vascular permeability by targeting prolyl hydroxylase and tight junction protein ZO-1. Oncogene. 2017;36:4929-42.

217. Webber JP, Spary LK, Sanders AJ, Chowdhury R, Jiang WG, Steadman R, Wymant J, Jones AT, Kynaston H, Mason MD, et al. Differentiation of tumour-promoting stromal myofibroblasts by cancer exosomes. Oncogene. 2015;34:290-302.

218. Lawson J, Dickman C, Towle R, Jabalee J, Javer A, Garnis C. Extracellular vesicle secretion of miR-142-3p from lung adenocarcinoma cells induces tumor promoting changes in the stroma through cell-cell communication. Mol Carcinog. 2019:58:376-87.

219. Lin J, Wang Y, Zou YQ, Chen X, Huang B, Liu J, Xu YM, Li J, Zhang J, Yang $W M$, et al. Differential miRNA expression in pleural effusions derived from extracellular vesicles of patients with lung cancer, pulmonary tuberculosis, or pneumonia. Tumour Biol. 2016;37:15835-45

220. Tamiya H, Mitani A, Saito A, Ishimori T, Saito M, Isago H, Jo T, Yamauchi Y, Tanaka G, Nagase T. Exosomal MicroRNA Expression Profiling in Patients with Lung Adenocarcinoma-associated Malignant Pleural Effusion. Anticancer Res. 2018;38:6707-14.

221. Wu H, Zhou J, Mei S, Wu D, Mu Z, Chen B, Xie Y, Ye Y, Liu J. Circulating exosomal microRNA-96 promotes cell proliferation, migration and drug resistance by targeting LMO7. J Cell Mol Med. 2017;21:1228-36.

222. Lei Y, Guo W, Chen B, Chen L, Gong J, Li W. Tumorreleased IncRNA H19 promotes gefitinib resistance via packaging into exosomes in nonsmall cell lung cancer. Oncol Rep. 2018;40:3438-46.

223. Zambon M, Vincent JL. Mortality rates for patients with acute lung injury/ ARDS have decreased over time. Chest. 2008;133:1120-7.

224. Eisner MD, Thompson T, Hudson LD, Luce JM, Hayden D, Schoenfeld D, Matthay MA. Acute Respiratory Distress Syndrome N: Efficacy of low tidal volume ventilation in patients with different clinical risk factors for acute lung injury and the acute respiratory distress syndrome. Am J Respir Crit Care Med. 2001;164:231-6,

225. Letsiou E, Sammani S, Zhang W, Zhou T, Quijada H, Moreno-Vinasco L, Dudek SM, Garcia JG. Pathologic mechanical stress and endotoxin exposure increases lung endothelial microparticle shedding. Am J Respir Cell Mol Biol. 2015;52:193-204.

226. Yu Y, Jing L, Zhang X, Gao C. Simvastatin Attenuates Acute Lung Injury via Regulating CDC42-PAK4 and Endothelial Microparticles. Shock. 2017;47:378-84.

227. Gao C, Li R, Liu Y, Ma L, Wang S. Rho-kinase-dependent F-actin rearrangement is involved in the release of endothelial microparticles during IFN-alpha-induced endothelial cell apoptosis. J Trauma Acute Care Surg. 2012;73:1152-60.

228. Li H, Meng X, Gao Y, Cai S. Isolation and phenotypic characteristics of microparticles in acute respiratory distress syndrome. Int J Clin Exp Pathol. 2015:8:1640-8.

229. Mitra S, Wewers MD, Sarkar A. Mononuclear Phagocyte-Derived Microparticulate Caspase-1 Induces Pulmonary Vascular Endothelial Cell Injury. PLoS One. 2015;10:e0145607.

230. Kerr NA, de Rivero Vaccari JP, Abbassi S, Kaur H, Zambrano R, Wu S, Dietrich WD, Keane RW. Traumatic Brain Injury-Induced Acute Lung Injury: Evidence for Activation and Inhibition of a Neural-Respiratory-Inflammasome Axis. J Neurotrauma. 2018;35:2067-76.

231. Buesing KL, Densmore JC, Kaul S, Pritchard KA Jr, Jarzembowski JA, Gourlay DM, Oldham KT. Endothelial microparticles induce inflammation in acute lung injury. J Surg Res. 2011;166:32-9.

232. Moon HG, Cao Y, Yang J, Lee JH, Choi HS, Jin Y. Lung epithelial cell-derived extracellular vesicles activate macrophage-mediated inflammatory responses via ROCK1 pathway. Cell Death Dis. 2015;6:e2016.

233. Lee H, Zhang D, Zhu Z, Dela Cruz CS, Jin Y. Epithelial cell-derived microvesicles activate macrophages and promote inflammation via microvesicle-containing microRNAs. Sci Rep. 2016;6:35250.

234. Zheng BB, Zhang Y, Sun NN, Huang WH. Meng Y: [Role and mechanism of lipopolysaccharide induced exosome in the pathogenesis of acute lung injury]. Zhonghua Yi Xue Za Zhi. 2018;98:1780-5.

235. Soni S, Wilson MR, O'Dea KP, Yoshida M, Katbeh U, Woods SJ, Takata M. Alveolar macrophage-derived microvesicles mediate acute lung injury. Thorax. 2016;71:1020-9.

236. Yuan Z, Bedi B, Sadikot RT. Bronchoalveolar Lavage Exosomes in Lipopolysaccharide-induced Septic Lung Injury. J Vis Exp. 2018;135:57737.

237. Li H, Meng X, Liang X, Gao Y, Cai S. Administration of microparticles from blood of the lipopolysaccharide-treated rats serves to induce pathologic changes of acute respiratory distress syndrome. Exp Biol Med (Maywood). 2015;240:1735-41.

238. Scheller N, Herold S, Kellner R, Bertrams W, Jung AL, Janga H, Greulich T, Schulte LN, Vogelmeier CF, Lohmeyer J, Schmeck B. Proviral MicroRNAs Detected in Extracellular Vesicles From Bronchoalveolar Lavage Fluid of Patients With Influenza Virus-Induced Acute Respiratory Distress Syndrome. J Infect Dis. 2019;219:540-3.

239. Lee H, Zhang D, Wu J, Otterbein LE, Jin Y. Lung Epithelial Cell-Derived Microvesicles Regulate Macrophage Migration via MicroRNA-17/221-Induced Integrin beta1 Recycling. J Immunol. 2017;199:1453-64.

240. Lee H, Zhang D, Laskin DL, Jin Y. Functional Evidence of Pulmonary Extracellular Vesicles in Infectious and Noninfectious Lung Inflammation. J Immunol. 2018;201:1500-9.

241. Dejager L, Pinheiro I, Dejonckheere E, Libert C. Cecal ligation and puncture: the gold standard model for polymicrobial sepsis? Trends Microbiol. 2011; 19:198-208.

242. Lee C, Mitsialis SA, Aslam M, Vitali SH, Vergadi E, Konstantinou G, Sdrimas K, Fernandez-Gonzalez A, Kourembanas S. Exosomes mediate the cytoprotective action of mesenchymal stromal cells on hypoxia-induced pulmonary hypertension. Circulation. 2012;126:2601-11.

243. Chen JY, An R, Liu ZJ, Wang JJ, Chen SZ, Hong MM, Liu JH, Xiao MY, Chen YF. Therapeutic effects of mesenchymal stem cell-derived microvesicles on pulmonary arterial hypertension in rats. Acta Pharmacol Sin. 2014;35:1121-8.

244. Hogan SE, Rodriguez Salazar MP, Cheadle J, Glenn R, Medrano C, Petersen $\mathrm{TH}$, llagan RM. Mesenchymal stromal cell-derived exosomes improve mitochondrial health in pulmonary arterial hypertension. Am J Physiol Lung Cell Mol Physiol. 2019;316:L723-37.

245. Belik D, Tsang H, Wharton J, Howard L, Bernabeu C, Wojciak-Stothard B, Endothelium-derived microparticles from chronically thromboembolic 
pulmonary hypertensive patients facilitate endothelial angiogenesis. J Biomed Sci. 2016;23:4.

246. Du YM, Zhuansun YX, Chen R, Lin L, Lin Y, Li JG. Mesenchymal stem cell exosomes promote immunosuppression of regulatory $T$ cells in asthma. Exp Cell Res. 2018;363:114-20.

247. de Castro LL, Xisto DG, Kitoko JZ, Cruz FF, Olsen PC, Redondo PAG, Ferreira TPT, Weiss DJ, Martins MA, Morales MM, Rocco PRM. Human adipose tissue mesenchymal stromal cells and their extracellular vesicles act differentially on lung mechanics and inflammation in experimental allergic asthma. Stem Cell Res Ther. 2017;8:151.

248. Cruz FF, Borg ZD, Goodwin M, Sokocevic D, Wagner DE, Coffey A, Antunes M, Robinson KL, Mitsialis SA, Kourembanas S, et al. Systemic Administration of Human Bone Marrow-Derived Mesenchymal Stromal Cell Extracellular Vesicles Ameliorates Aspergillus Hyphal Extract-Induced Allergic Airway Inflammation in Immunocompetent Mice. Stem Cells Transl Med. 2015;4: 1302-16.

249. Ding FX, Liu B, Zou WJ, Li QB, Tian DY, Fu Z. Pseudomonas aeruginosaderived exosomes ameliorates allergic reactions via inducing the Treg response in asthma. Pediatr Res. 2018;84:125-33.

250. Fang SB, Zhang HY, Wang C, He BX, Liu XQ, Meng XC, Peng YQ, Xu ZB, Fan $X L, W u Z J$, et al. Small extracellular vesicles derived from human mesenchymal stromal cells prevent group 2 innate lymphoid cell-dominant allergic airway inflammation through delivery of miR-146a-5p. J Extracell Vesicles. 2020;9:1723260.

251. Morse MA, Garst J, Osada T, Khan S, Hobeika A, Clay TM, Valente N, Shreeniwas R, Sutton MA, Delcayre A, et al. A phase I study of dexosome immunotherapy in patients with advanced non-small cell lung cancer. J Transl Med. 2005;3:9.

252. Zhu YG, Feng XM, Abbott J, Fang XH, Hao Q, Monsel A, Qu JM, Matthay MA, Lee JW. Human mesenchymal stem cell microvesicles for treatment of Escherichia coli endotoxin-induced acute lung injury in mice. Stem Cells. 2014;32:116-25.

253. Phinney DG, Di Giuseppe M, Njah J, Sala E, Shiva S, St Croix CM, Stolz DB, Watkins SC, Di YP, Leikauf GD, et al. Mesenchymal stem cells use extracellular vesicles to outsource mitophagy and shuttle microRNAs. Nat Commun. 2015;6:8472.

254. Morrison TJ, Jackson MV, Cunningham EK, Kissenpfennig A, McAuley DF, O'Kane CM, Krasnodembskaya AD. Mesenchymal Stromal Cells Modulate Macrophages in Clinically Relevant Lung Injury Models by Extracellular Vesicle Mitochondrial Transfer. Am J Respir Crit Care Med. 2017;196: 1275-86.

255. Shah T, Qin S, Vashi M, Predescu DN, Jeganathan N, Bardita C, Ganesh B, DiBartolo S, Fogg LF, Balk RA, Predescu SA. Alk5/Runx1 signaling mediated by extracellular vesicles promotes vascular repair in acute respiratory distress syndrome. Clin Transl Med. 2018;7:19.

256. Potter DR, Miyazawa BY, Gibb SL, Deng X, Togaratti PP, Croze RH, Srivastava AK, Trivedi A, Matthay M, Holcomb JB, et al. Mesenchymal stem cell-derived extracellular vesicles attenuate pulmonary vascular permeability and lung injury induced by hemorrhagic shock and trauma. J Trauma Acute Care Surg. 2018;84:245-56.

257. Park J, Kim S, Lim H, Liu A, Hu S, Lee J, Zhuo H, Hao O Matthay MA, Lee JW. Therapeutic effects of human mesenchymal stem cell microvesicles in an ex vivo perfused human lung injured with severe E. coli pneumonia. Thorax. 2019;74:43-50

258. Loy H, Kuok DIT, Hui KPY, Choi MHL, Yuen W, Nicholls JM, Peiris JSM, Chan MCW. Therapeutic Implications of Human Umbilical Cord Mesenchymal Stromal Cells in Attenuating Influenza A(H5N1) Virus-Associated Acute Lung Injury. J Infect Dis. 2019;219:186-96.

259. Wu X, Liu Z, Hu L, Gu W, Zhu L. Exosomes derived from endothelial progenitor cells ameliorate acute lung injury by transferring miR-126. Exp Cell Res. 2018;370:13-23.

260. Ju Z, Ma J, Wang C, Yu J, Qiao Y, Hei F. Exosomes from iPSCs Delivering siRNA Attenuate Intracellular Adhesion Molecule-1 Expression and Neutrophils Adhesion in Pulmonary Microvascular Endothelial Cells. Inflammation. 2017:40:486-96.

261. Salimian J, Mirzaei H, Moridikia A, Harchegani AB, Sahebkar A, Salehi H. Chronic obstructive pulmonary disease: MicroRNAs and exosomes as new diagnostic and therapeutic biomarkers. J Res Med Sci. 2018;23:27.

262. Fujita Y, Kadota T, Araya J, Ochiya T, Kuwano K. Clinical Application of Mesenchymal Stem Cell-Derived Extracellular Vesicle-Based Therapeutics for Inflammatory Lung Diseases. J Clin Med. 2018;7:355.
263. Mohammadipoor A, Antebi B, Batchinsky Al, Cancio LC. Therapeutic potential of products derived from mesenchymal stem/stromal cells in pulmonary disease. Respir Res. 2018;19:218.

264. Abreu SC, Weiss DJ, Rocco PR. Extracellular vesicles derived from mesenchymal stromal cells: a therapeutic option in respiratory diseases? Stem Cell Res Ther. 2016;7:53.

265. Hogan SE, Rodriguez Salazar MP, Cheadle J, Glenn R, Medrano C, Petersen $\mathrm{TH}$, llagan RM. Mesenchymal Stromal Cell-Derived Exosomes Improve Mitochondrial Health in Pulmonary Arterial Hypertension. Am J Physiol Lung Cell Mol Physiol. 2019;316:L723-37.

266. Gu J, Zhang H, Ji B, Jiang H, Zhao T, Jiang R, Zhang Z, Tan S, Ahmed A, Gu Y. Vesicle miR-195 derived from Endothelial Cells Inhibits Expression of Serotonin Transporter in Vessel Smooth Muscle Cells. Sci Rep. 2017;7:43546.

267. Delcayre A, Shu H, Le Pecq JB. Dendritic cell-derived exosomes in cancer immunotherapy: exploiting nature's antigen delivery pathway. Expert Rev Anticancer Ther. 2005;5:537-47.

268. Le Pecq JB. Dexosomes as a therapeutic cancer vaccine: from bench to bedside. Blood Cells Mol Dis. 2005;35:129-35.

269. Naslund TI, Gehrmann U, Gabrielsson S. Cancer immunotherapy with exosomes requires B-cell activation. Oncoimmunology. 2013;2:e24533.

270. Huang C, Liu S, Tong X, Fan H. Extracellular vesicles and ctDNA in lung cancer: biomarker sources and therapeutic applications. Cancer Chemother Pharmacol. 2018;82:171-83.

271. Inamura K. Lung Cancer: Understanding Its Molecular Pathology and the 2015 WHO Classification. Front Oncol. 2017;7:193.

\section{Publisher's Note}

Springer Nature remains neutral with regard to jurisdictional claims in published maps and institutional affiliations.
Ready to submit your research? Choose BMC and benefit from:
- fast, convenient online submission
- thorough peer review by experienced researchers in your field
- rapid publication on acceptance
- support for research data, including large and complex data types
- gold Open Access which fosters wider collaboration and increased citations
- maximum visibility for your research: over $100 \mathrm{M}$ website views per year
At BMC, research is always in progress.
Learn more biomedcentral.com/submissions 